Accepted refereed manuscript of:

Krabbendam M, Bradwell T, Everest JD \& Eyles N (2017) Joint-bounded crescentic scars formed by subglacial clast-bed contact forces: Implications for bedrock failure beneath glaciers, Geomorphology, 290, pp. 114-127.

DOI: $10.1016 /$ j.geomorph.2017.03.021

(C) 2017, Elsevier. Licensed under the Creative Commons AttributionNonCommercial-NoDerivatives 4.0 International http://creativecommons.org/licenses/by-nc-nd/4.0/ 


\title{
Joint-bounded crescentic scars formed by subglacial clast-bed contact forces: implications for bedrock failure beneath glaciers
}

\author{
M. Krabbendam ${ }^{\mathrm{a}, *}$, T. Bradwell ${ }^{\mathrm{a}, \mathrm{b}}$, J.D. Everest ${ }^{\mathrm{a}}$, N. Eyles ${ }^{\mathrm{c}}$ \\ ${ }^{a}$ British Geological Survey, Lyell Centre, Research Avenue South, Edinburgh, UK \\ ${ }^{\mathrm{b}}$ Biological and Environmental Sciences, University of Stirling, Stirling, UK \\ ${ }^{\mathrm{c}}$ Physical and Environmental Sciences, University of Toronto, Scarborough, ON M1C 1A4, Canada \\ *Corresponding author: Tel +44 131 6500256; mkrab@bgs.ac.uk (M. Krabbendam)
}

\begin{abstract}
Glaciers and ice sheets are important agents of bedrock erosion, yet the precise processes of bedrock failure beneath glacier ice are incompletely known. Subglacially formed erosional crescentic markings (crescentic gouges, lunate fractures) on bedrock surfaces occur locally in glaciated areas and comprise a conchoidal fracture dipping down-ice and a steep fracture that faces up-ice. Here we report morphologically distinct crescentic scars that are closely associated with preexisting joints, termed here joint-bounded crescentic scars. These hitherto unreported features are ca. 50-200 mm deep and involve considerably more rock removal than previously described crescentic markings. The joint-bounded crescentic scars were found on abraded rhyolite surfaces recently exposed (<20 years) beneath a retreating glacier in Iceland, as well as on glacially sculpted Precambrian gneisses in NW Scotland and various Precambrian rocks in Ontario, glaciated during the Late Pleistocene. We suggest a common formation mechanism for these contemporary and relict features, whereby a boulder embedded in basal ice produces a continuously migrating clast-bed contact force as it is dragged over the hard (bedrock) bed. As the ice-embedded boulder approaches a preexisting joint in the bedrock, stress concentrations build up in the bed that exceed the intact rock strength, resulting in conchoidal fracturing and detachment of a crescentic wedge-shaped rock fragment. Subsequent removal of the rock fragment probably involves further fracturing or crushing (comminution) under high contact forces. Formation of joint-bounded crescentic scars is favoured by large boulders at the base of the ice, high basal melting rates, and the presence of preexisting subvertical joints in the bedrock bed. We infer that the relative scarcity of crescentic markings in general on deglaciated surfaces shows that fracturing of intact bedrock below ice is difficult, but that preexisting weaknesses such as joints greatly facilitate rock failure. This implies that models of glacial erosion need to take fracture patterns of bedrock into account.
\end{abstract}

Keywords: conchoidal fracture; subglacial erosion; joint; rock strength 


\section{Introduction}

The two main mechanisms of subglacial erosion of hard bedrock beneath glaciers and ice sheets are generally regarded to be abrasion and plucking (quarrying), with an added component of subglacial meltwater erosion (e.g., Drewry, 1986; Glasser and Bennett, 2004). A major challenge in understanding plucking has been the need to explain the failure (breaking) of hard bedrock by moving ice (e.g., Morland and Boulton, 1975; Iverson, 1991; Hallet, 1996). Ice has a shear strength and a compressive strength that is much lower than most intact rock types (see Table 1), and envisaging how such a weak material can fracture a much stronger material is difficult. More recent studies have now established that most, if not all, plucking occurs along preexisting fractures (joints) so that intact bedrock need not be fractured directly by ice above it (Rea, 1994; Dühnforth et al., 2010; Krabbendam and Glasser, 2011; Hooyer et al., 2012; Iverson, 2012). In essence, preexisting weaknesses such as joints (typically formed by uplift, cooling, or tectonic stresses) are merely exploited by the plucking process to further break apart the rock. However, the occurrence of crescentic markings - a family of small-scale erosional bedforms all characterised by conchoidal fracturing - suggests that fracturing of intact bedrock does occur below glaciers and ice sheets under certain circumstances.

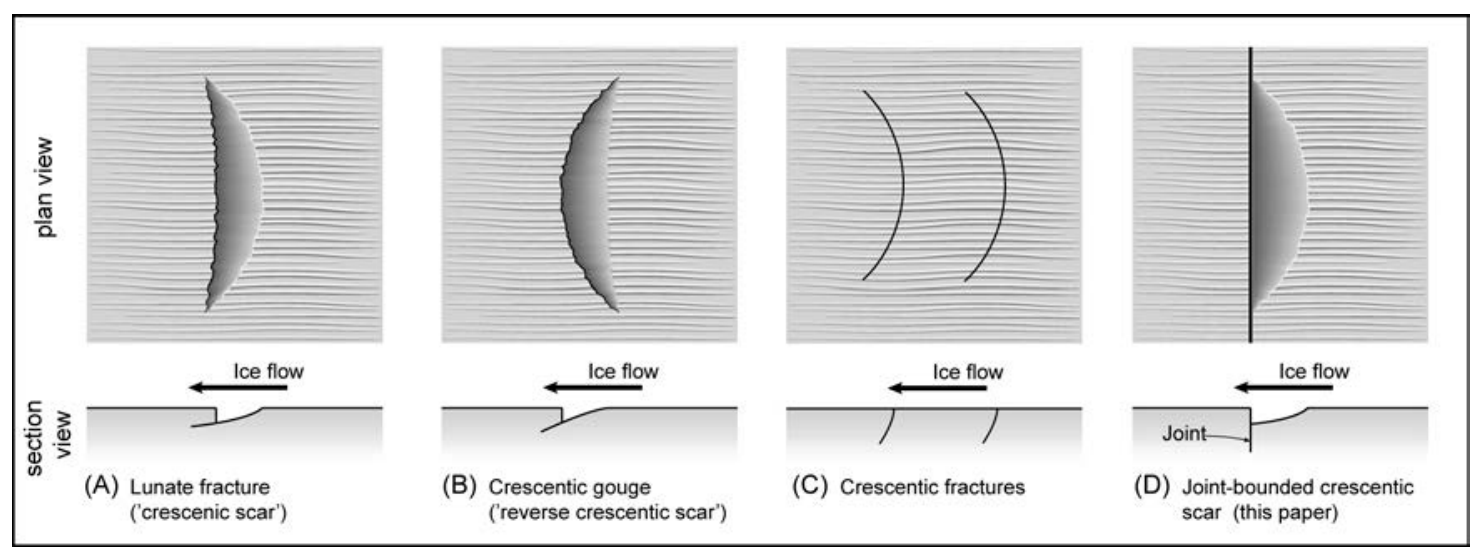

Fig. 1. Crescentic markings, in plan view (top) and cross-section (bottom); modified after Embleton and King (1975), with terminology of Prest (1983) in brackets. (A) lunate fracture or crescentic scar; (B) crescentic gouge or reverse crescentic scar; (C) crescentic fractures, without removal of bedrock; (D) joint-bounded crescentic scar (this paper). Note different relation between conchoidal fracture and subvertical fracture / joint. The conchoidal fracture invariably dips in the direction of ice flow.

Crescentic markings include crescentic gouges, lunate fractures, and crescentic fractures (Chamberlin, 1888; Gilbert, 1906; Lahee, 1912; Harris, 1943; Okko, 1950; Dreimanis, 1953; Slocum, 1978; Wintges, 1985; Glasser and Bennett, 2004). Different names have been used to describe these (shown in brackets in Fig. 1); we prefer the descriptive term crescentic markings here as a collective term above the interpretational term friction cracks (cf. Harris, 1943). The term chattermarks is at times used as a general term (see discussion in Harris, 1943); more strictly they refer to a series of fractures confined to grooves (Benn and Evans, 1998), but the fractures may not necessarily be crescentic (Harris, 1943). Most crescentic markings have been reported on massive, unfoliated, or poorly foliated bedrock such as granite, sandstone, or quartzite (Chamberlin, 1888; Harris, 1943; Okko, 1950; Slocum, 1978; 
Wintges, 1985). There is general agreement that crescentic markings are formed by high clast-bed contact forces, exerted by large cobbles or boulders embedded in basal ice pressing onto the bed (Gilbert, 1906; Harris, 1943; Hallet, 1979; Ficker et al., 1980; Wintges, 1985; Drewry, 1986; Glasser and Bennett, 2004). The occurrence of crescentic markings may thus provide information about the subglacial conditions under which high clast-bed contact forces and bedrock failure can develop.
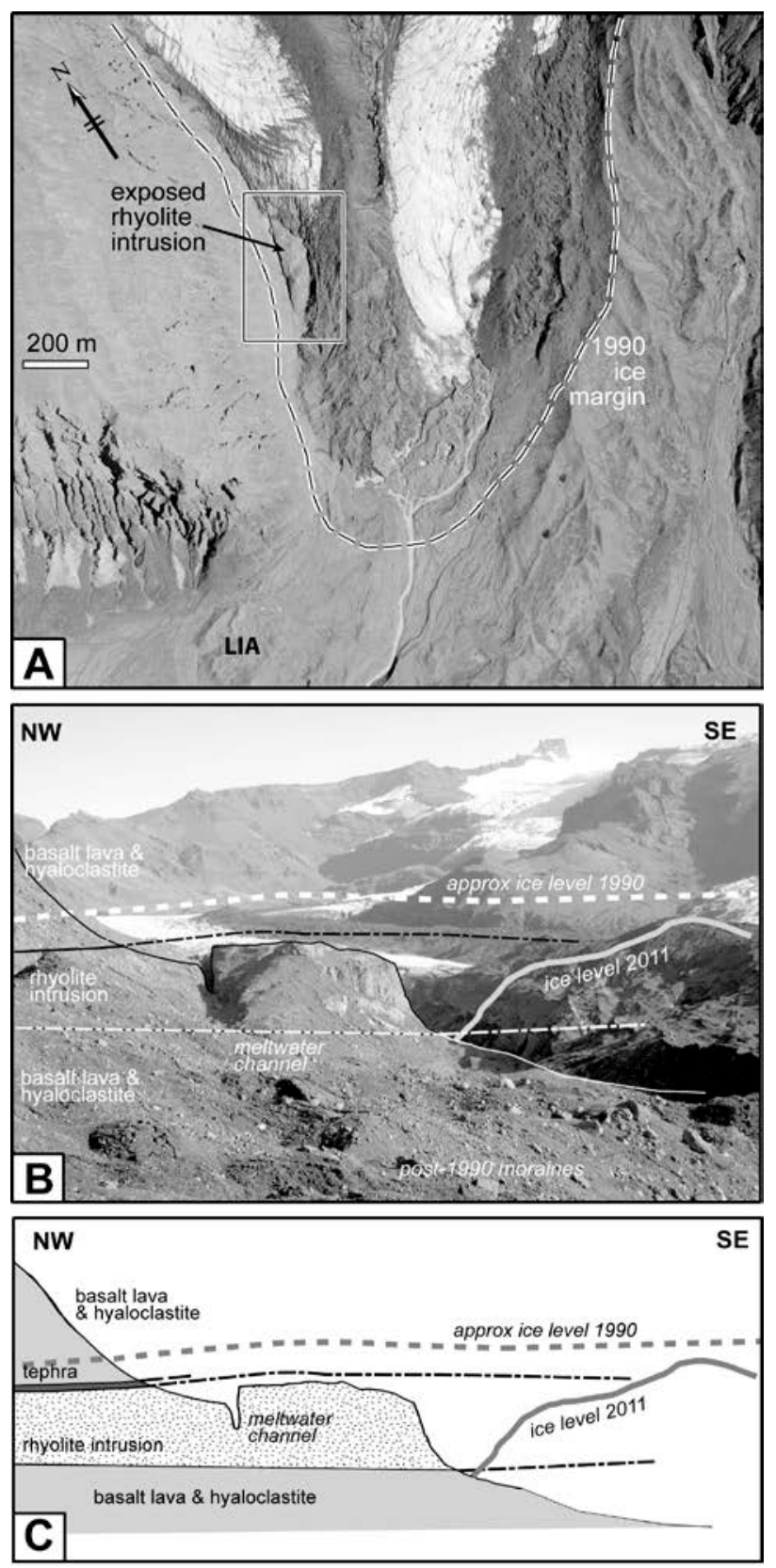

Fig. 2. Setting of study area of Virkisjökull in SE Iceland. (A) Vertical air photo (August 2007; NERC Airborne Research Survey Facility image 20070802006622, 2007) of part of ablation zone of Virkisjökull. Location of studied bedrock high and approximate ice margin at 1990 are indicated. Much of the ice in 2011 is covered in debris. LIA is part of Little Ice Age moraine. (B) View to the NNE of the study area: the bedrock high on the NW side of the ablation zone of Virkisjökull. Geological boundaries same as cross section. (C) Geological cross section through bedrock high, with 1990 and 2011 ice levels shown.

During work around the British Geological Survey Virkisjökull Glacial Observatory in southern Iceland, very well preserved, small- and medium-scale erosional bedforms were noted on a recently ( $<20$ years) exposed bedrock high (Fig. 2). We noted numerous crescentic scars that are intimately related with preexisting, preglacial joints in the bedrock; an association that, to our knowledge, has not been reported before. Here, we define these as joint-bounded crescentic scars. In this paper we present a detailed analysis of these bedforms identified at Virkisjökull alongside the properties of the bedrock. 
Joint-bounded crescentic scars were also found on Precambrian gneiss in the NW Highlands of Scotland and on various Precambrian lithologies on the Canadian Shield of Ontario, Canada. These relict examples developed during Pleistocene glaciation(s). We go on to discuss how high clast-bed contact forces can be generated below ice; how these can result in stresses that exceed the strength of the bed adjacent to joints; we propose a formation mechanism for joint-bounded crescentic scars; and finally discuss how these bedforms can inform us about the circumstances under which bedrock failure of the glacier bed may occur.

\section{Methods}

Detailed geological and geomorphological observations were made in the study area in Iceland, including orientations of glacial striae and bedrock joints, along with depth and angle of joint-bounded crescentic scars. On a number of level bedrock surfaces, vertical photos were taken with a scale, carefully oriented to true north. These photos were georeferenced in ArcGIS in an artificial coordinate system, in essence creating a georeferenced outcrop-scale aerial photo from a height of ca. $2 \mathrm{~m}$ (Fig. 3). Glacial striae and the outline and long axes of crescentic scars were digitised on the georeferenced images. From these digital lines, the orientation and length were extracted (using ArcTools and a spreadsheet); these are presented in rose diagrams made using Stereonet V8 software (Cardozo and Allmendinger, 2013). Joint analysis uses the principle of the circle inventory method (Davis and Reynolds, 1996, p. 720) to prevent any directional bias, but was speeded up by using the georeferenced outcrop photos. Circles of known area were drawn in the GIS and all joint traces were digitised within that particular circle (see also Krabbendam and Bradwell, 2014). Joint orientations can then be easily extracted from the data set and presented in rose diagrams, using the same method as the striae.

Schmidt Hammer rebound values are a function of rock hardness and show an empirical exponential relationship with uniaxial compressive strength (Aydin and Basu, 2005) and can thus be regarded as a proxy for intact rock strength. Schmidt Hammer (type-N) rebound measurements were taken on outcrops away from edges and joints, as well as on a number of large ( $>1 \mathrm{~m}$ ) boulders. Only smooth surfaces were tested. Ten blows per site were performed in slightly different positions. Anomalous values, typically on the low side, were rejected; the average of the remainder were taken as the rebound measurement. 


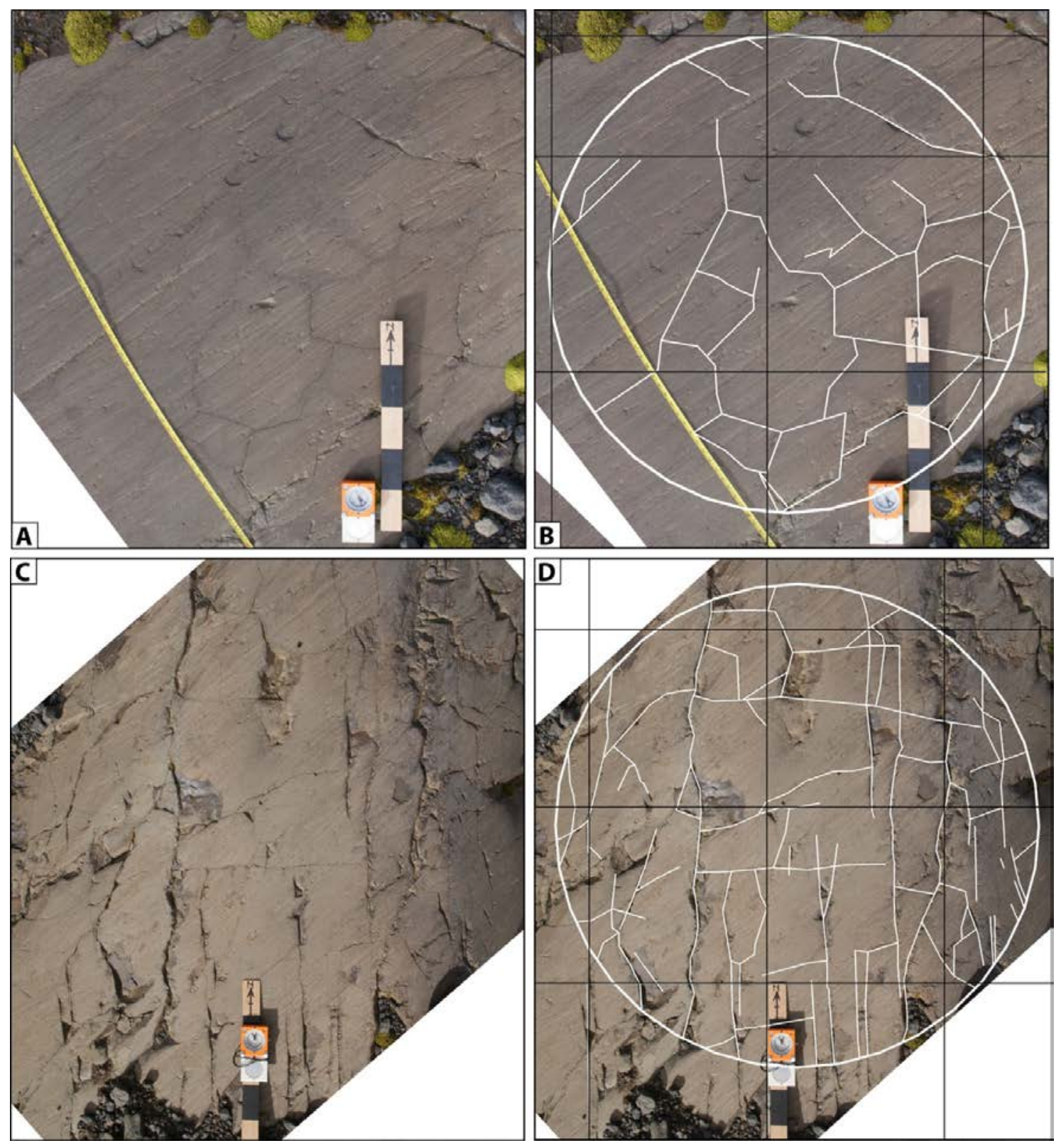

Fig. 3. Outcrop photos, planview, for joint analysis. (A) Planview photo of surface showing columnar jointing. (B) As previous, georeferenced, with circle and grid superimposed, and digitised traces of joints. (C) Planview of typical conjugate jointing. (D) As previous, georeferenced, with circle and grid superimposed, and digitised traces of joints. North to top, black and white marks on ruler have 10-cm spacing, grid on (B) and (D) has 50-cm spacing. Photos taken ca. $2 \mathrm{~m}$ above surface.

\section{Glaciology, geology, and geomorphology background, Virkisjökull, Iceland}

Virkisjökull is an outlet glacier draining the Öraefajökull Ice Cap in southern Iceland, which largely covers the Öraefajökull volcano, one of the largest active volcanoes in Iceland. Öraefajökull volcano consists mainly of basaltic hyaloclastite (volcanic breccias formed by lava-ice and lava-water interaction), basaltic tuffs, basalt lava flows, and minor rhyolitic intrusions (Prestvik, 1979; Stevenson et al., 2006). Virkisjökull has experienced jökulhlaups, most recently during an eruption in 1362 CE (Thorarinsson, 1958). Bradwell et al. (2013) provided a detailed glaciological description of Virkisjökull and its recent history of rapid retreat (ca. $40 \mathrm{~m} \mathrm{y}^{-1}$; 1995-2012), which has revealed a 
bedrock high on the northwest margin of the glacier ablation zone (Figs. 2A, B, 4A). This bedrock high comprises the main study area; it is elongate (300 m wide, $100 \mathrm{~m}$ long) broadly parallel to ice flow, and varies in height between 20 and $40 \mathrm{~m}$. The top surface of the bedrock high is ca. $100 \mathrm{~m}$ below the maximum level attained by the glacier surface in the Little Ice Age, and the lee side is ca. 1 $\mathrm{km}$ from the Little Ice Age terminal moraine reached in about 1890 CE (Thorarinsson, 1943). The bedrock high is composed of rhyolitic rock, intruded into the volcanic edifice probably as a subhorizontal, lens-shaped sill, with basalt lava flows, and hyaloclastite and tuff deposits above and below (Figs. 2B, C). The rhyolite sill is ca. $40 \mathrm{~m}$ thick, with a horizontal extent $>500 \mathrm{~m}$.

The stoss side on the northern side of the bedrock high was still partially in contact with ice (in September 2013). Where deglaciated, the stoss side is steep but rounded, smooth bedrock, with steep striae with variable orientations. On subvertical parts of some stoss sides, small pits, with surface areas of 10-60 $\mathrm{mm}^{2}$, were observed (Fig. 4C); these were likely formed by crushing or gouging by large clasts pressed against the stoss side. The southern lee side of the bedrock high shows plucked bedrock faces in a stepped topography as well as fairly steep (ca. $35-40^{\circ}$ ) abraded surfaces, but lower down it is covered by loose morainic debris (Fig. 4A). The lateral ESE face of the bedrock high is a subvertical cliff (ca. $30 \mathrm{~m}$ high), showing columnar jointing (Figs. 4A, B). Horizontal striae are abundant on this face, and lateral plucking (e.g., Krabbendam and Bradwell, 2011) is also evident. To the west, the bedrock high is separated from the main valley slope by a straight, 10-20 m deep, 1-3 m wide slot canyon, interpreted as a subglacial meltwater channel, possibly following a fracture zone or a fault (Figs. 2, 4A, B).

Loose debris is abundant on the bedrock surface (Fig. 4D); it is poorly sorted and variably rounded: cobbles and boulders 10-60 cm across are most common, but some are up to ca. $2 \mathrm{~m}$ across. This material represents debris formerly contained in basal ice. Much debris must have entered the glacier from the steep, unstable valley slopes. One example of this supply is a recent (winter 20102011) rockfall, which deposited ca. 100,000 $\mathrm{m}^{3}$ (G. Gudmundsson, Icelandic Met Office, personal communication) of rock onto the side of the glacier (Fig. 4E). Such events ensure a rich supply of coarse supraglacial debris onto the glacier that, especially on the lateral side, can work its way to the ice bed, aided by crevasses.

The bedrock high shows an abundance of smoothed, polished bedrock on level surfaces and on various whalebacks and roche moutonnées. Two sets of striae occur. The dominant set (main set) is ubiquitous and comprises pervasive, densely spaced to overlapping, long thin striae (Fig. 4F), with a uniform orientation toward $227^{\circ}$ (Fig. 5A) parallel to the main axis of the glacier. The dominant set of striae curves around whalebacks and roches moutonnées (similar to that described by Rastas and Seppälä, 1981). A second late set of striae is widely spaced and occurs on some outcrops only. The late set striae are deep, cut across and through the dominant set, vary greatly in length (ca. 0.3-3 m), have more variable orientations (230-260 $)$, and most likely developed during glacier retreat, with more flow toward the side of the glacier (e.g., Chamberlin, 1888). Plucked faces, on the lee side of 

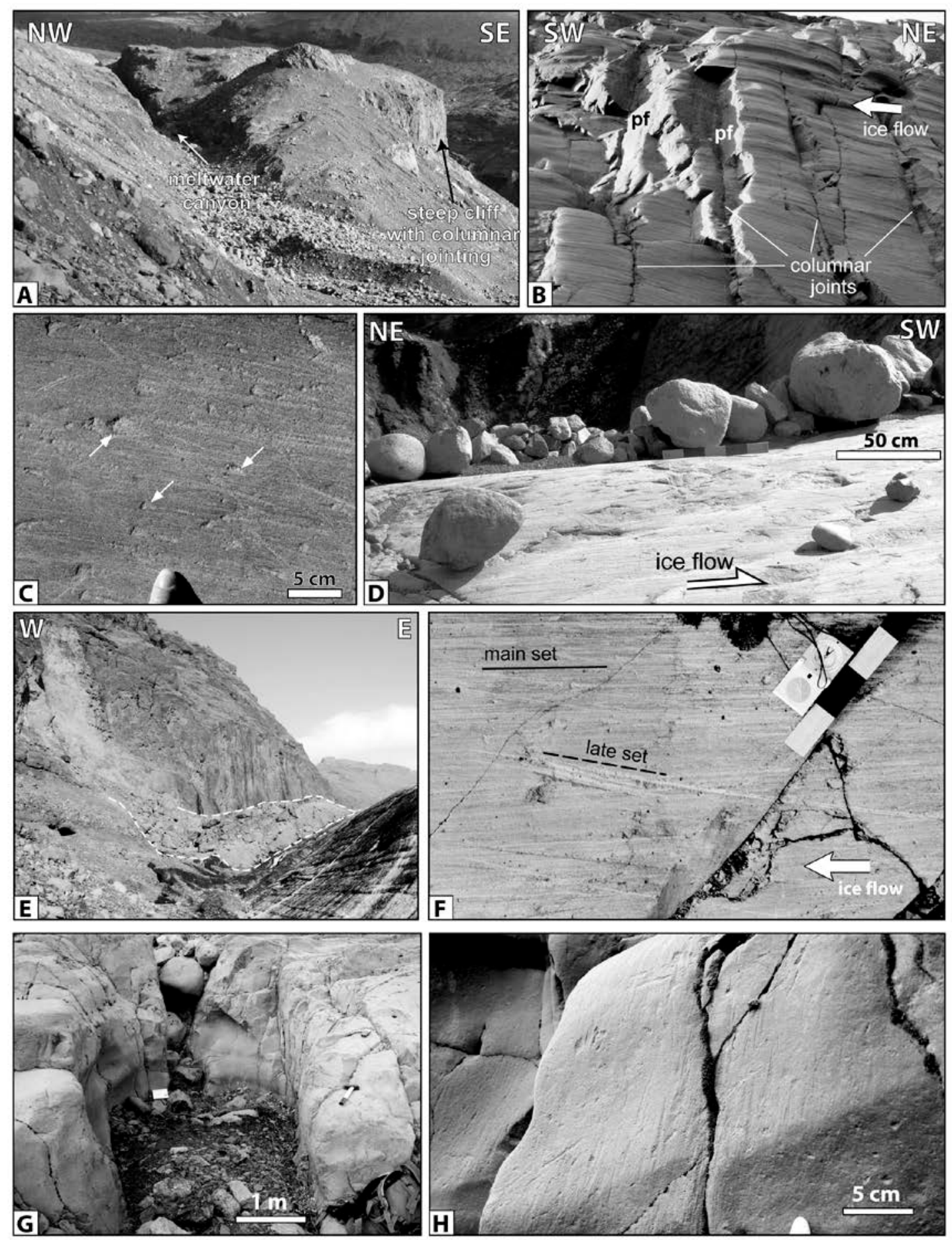

Fig. 4. Features at Virkisjökull. (A) Bedrock high, with narrow meltwater channel to the NW and steep lateral slope to the SE. Morainic debris on lee-side (toward viewer). (B) Upward view of the SE lateral wall, showing vertical columnar joints and horizontal striae indicating strong lateral ice flow. Faces marked pf show lateral plucking. (C) Crushing pits (selection is arrowed in) and short, incipient striae on stoss side of bedrock high. Overall ice flow at ca. $80^{\circ}$ of surface. (D) Abraded bedrock surface with clasts of basalt and rhyolite, 10-70 cm diameter. (E) Large rock fall, partially onto glacier. Rock fall occurred in winter 2010-2011, photo taken September 2011. Height of scar ca. $200 \mathrm{~m}$. Outline of rock fall highlighted for clarity. Ice appears dark caused by ash fall from Grimsvatn eruption, May 2011. (F) Level surface on top of bedrock high, showing main set and late set of striae. Planview; scale bar divisions are $10 \mathrm{~cm}$ long . (G) Large pothole, formed by subglacial meltwater erosion, just NW of deep meltwater channel. (H) Vertical striae in top part of meltwater canyon. 
roches moutonnées and rock steps, are associated with preexisting joints and indicate strong joint control on plucking (Rea, 1994, Krabbendam and Glasser, 2011; Hooyer et al., 2012).

Numerous bedforms indicate locally vigorous meltwater erosion. These include (i) potholes, 0.3-3 m across (Fig. 4G); (ii) scalloped, moulded surfaces without striae on the lee sides of some roche moutonnées; (iii) steep, subvertical S-forms, including a subvertical half-pipe without striae on the steep stoss side of a small rock wall; and (iv) the slot canyon to the west, which also shows scalloped surfaces, generally free of striae. The scalloped surfaces suggest erosion under phreatic conditions. On the upper parts of the canyon wall, deep vertical striae occur (Fig. 4H), and in one place vertical and horizontal striae occur. One explanation for these latter features is that during high meltwater discharge events, ice melted out of the channel creating a tunnel (4-6 m high), whereas when meltwater flow dropped, the ice flowed back subvertically into the canyon. Measurements in the present-day proglacial river show highly variable discharge, which can fluctuate by a factor of 240 (2011-2014 measurements; MacDonald et al., 2016).

\section{Results}

\subsection{Virkisjökull - bedrock fractures, joints and hardness}

The rhyolite is fine-grained, essentially homogenous; there is no foliation. The top few metres of the rhyolite sill is vesicular. Two types of joints were found: columnar joints and conjugate joints. Columnar joints are well exposed on the steep cliff that bounds the bedrock high to the east (Fig. 4B); on this vertical face the joint spacing varies between 20 and $150 \mathrm{~cm}$. On the level top surface, columnar jointing appears as polygonal fractures and individual joint traces are $<1 \mathrm{~m}$ long in map view (Figs. 3A, B). Using the circle method (see methods section), 757 joints were digitised; of these the polygonal set $(n=488)$ shows poor preferred orientation, whereas joints in a conjugate set $(n=270)$ shows strong preferred orientation (Figs. 5C, D, E). Conjugate joints typically are several metres long (Figs. 3C, D) and can thus be separated on the basis of length and continuity of the individual joints. In some outcrops, the conjugate set was dominant and their orientations show a dominant NNE-SSW set and a subordinate ENE-WSW set (Fig. 5E). Most conjugate joints are wider (larger aperture) than the columnar joints, which are typically very tight (Fig. 3). Columnar, polygonal jointing is a common feature in volcanic rocks and is undoubtedly of non-glacial origin. Conjugate jointing is typically produced by tectonic stresses and, given the overall extensional tectonic regime in Iceland, these joints are also regarded as non-glacial in origin.

The Schmidt Hammer rebound values obtained for rhyolite are between $R=51$ and 52 (interquartile ranges quoted in text; see Table 1 for full range and standard deviation). Vesicular rhyolite has a lower hardness, between $R=46$ and 48, consistent with their higher porosity. Basalt clasts were noticeably harder $(\mathrm{R}=53-56)$, but lower values were obtained in vesicular basalt $(R=50-52)$. Tuff layers have very low hardness $(R=22-28)$. The hyaloclastite breccia comprises hard basalt clasts $(R=54-58)$ of varying size $(<1-20 \mathrm{~cm})$ set in a matrix of tuff-like material, with much lower rebound values $(R=25$ 32). The values for nonvesicular basalt and rhyolite compare well with those of similar rocks (e.g., 
microgranite) in the literature (Table 1), and other mechanical properties obtained by laboratory measurements are broadly applicable to the rocks discussed here. Thus, the clasts that lie on the bedrock surface (Fig. 4D) include basalt clasts that have equal or higher hardness, stiffness, and tensile and compressive strength than the rhyolite bed.

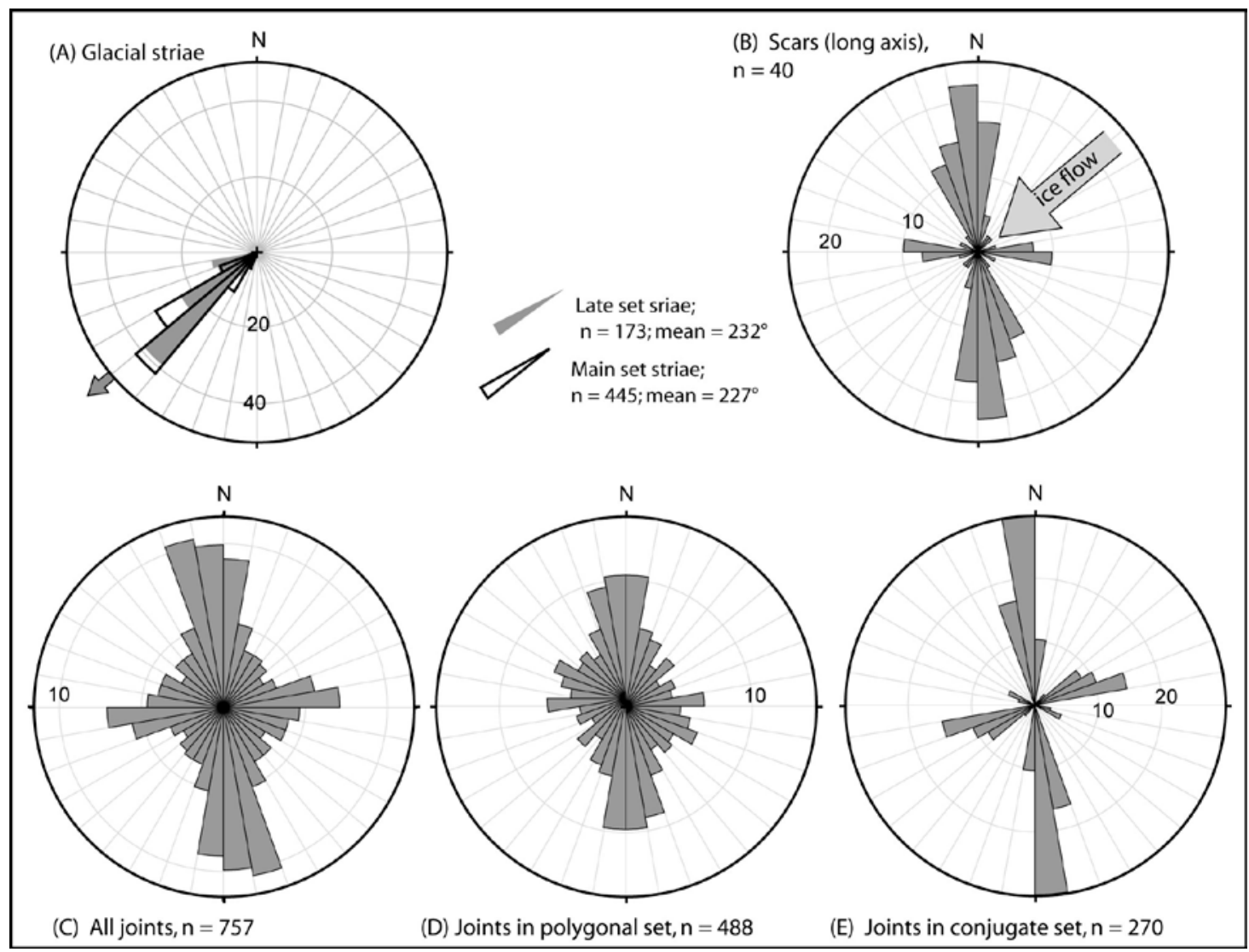

Fig. 5. Rose diagrams showing orientations of (A) glacial striae, separated into main set and late set; (B) long axes of crescentic scars, compared to ice flow; (C) all joints; (D) joints in polygonal set, related to columnar jointing; (E) joints in conjugate set, related to tectonic stresses. Note coincidence of orientation of long axes of crescentic scars and the conjugate joint set, as well as obliquity of crescentic scars with respect to ice flow direction. 


\begin{tabular}{|c|c|c|c|c|c|c|c|c|}
\hline & Rhyolite & $\begin{array}{l}\text { Rhyolite, } \\
\text { vesicular }\end{array}$ & Basalt & $\begin{array}{c}\text { Basalt, } \\
\text { vesicular }\end{array}$ & $\begin{array}{c}\text { Basalt clasts } \\
\text { within } \\
\text { hyaloclastite }\end{array}$ & $\begin{array}{c}\text { Hyaloclastite } \\
\text { matrix }\end{array}$ & Tuff & Ice \\
\hline \multicolumn{9}{|l|}{$\begin{array}{l}\text { Schmidt hammer (R } \\
\text { value) - this study }\end{array}$} \\
\hline mean & 51.6 & 47.3 & 54.5 & 51.4 & 55.9 & 29.1 & 25.3 & \\
\hline standard deviation & 1.3 & 1.9 & 2.6 & 2.4 & 3.3 & 5.7 & 5.2 & \\
\hline range & $48-53$ & $43-50$ & $48-61$ & $47-57$ & $50-61$ & $22-42$ & $16-30$ & \\
\hline interquartile range & $51-52$ & $46-48$ & $53-56$ & $50-52$ & $54-58$ & $25-32$ & $22-28$ & \\
\hline$n$ & 16 & 15 & 33 & 16 & 12 & 18 & 7 & \\
\hline $\begin{array}{l}\text { uniaxial compressive } \\
\text { strength (MPa) }\end{array}$ & $45-200$ & & $160-360$ & & & & & $5-25$ \\
\hline $\begin{array}{l}\text { tensile strength } \\
\text { (MPa) }\end{array}$ & $5-15$ & & $10-30$ & & & & & $0.7-3.1$ \\
\hline $\begin{array}{l}\text { Young's Modulus } \\
\text { (Gpa) }\end{array}$ & $10-50$ & & $40-80$ & & & & & $9.7-11.2$ \\
\hline Source & $\begin{array}{l}\text { Microgranite: } \\
\text { Adebayo et } \\
\text { al.(2010) ; Din } \\
\text { and Rafiq } \\
\text { (1997) }\end{array}$ & & $\begin{array}{l}\text { Schultz } \\
(1995)\end{array}$ & & & & & $\begin{array}{c}\text { Drewry } \\
\text { (1986). } \\
\text { Petrovic } \\
\text { (2003) }\end{array}$ \\
\hline
\end{tabular}

Table 1. Schmidt Hammer rebound data (R values), equivalent to rock hardness, collected on various lithologies (Virkisjökull, SE Iceland; this study). Mechanical properties of basalt and microgranite (used as a proxy for rhyolite) and ice from various sources.

\begin{tabular}{lcccc}
\hline & Length (cm) & Width $\mathbf{( c m )}$ & L/W ratio & Area $\left.\mathbf{( c m}^{2}\right)$ \\
\hline range & $2.0-67.8$ & $0.9-18.2$ & $0.7-7.3$ & $2.3-238.3$ \\
interquartile range & $5.4-17.5$ & $2.1-5.8$ & $1.8-4.3$ & $8.0-47.8$ \\
median & 9.6 & 3.4 & 2.6 & 25.5 \\
mean & 14 & 4.6 & 3.3 & 64.3 \\
standard deviation & 12.4 & 3.4 & 1.8 & 129.6 \\
\hline
\end{tabular}

Table 2. Dimensions of crescentic scars, from level surfaces only, $n=59$

\subsection{Virkisjökull: joint-bounded crescentic scars}

At Virkisjökull numerous joint-bounded crescentic scars occur on smoothed, abraded bedrock surfaces on top of the bedrock high. The crescentic scars have two components: (1) a concave, low-angle, conchoidal fracture that dips in the direction of ice flow; and (2) a straight subvertical fracture that faces against the ice flow (Figs. 1D, 6A-D). The two fractures delineate a crescentic wedge-shaped rock fragment, subsequently removed by ice, leaving a crescentic scar. The subvertical fractures are invariably contiguous with preexisting joints that are much longer than the length of the scars and continue through the rock well away from the scar. In most cases, the subvertical fracture is coincident with a single joint, commonly part of the N-S trending conjugate joint set (Figs. 6A, B, C). 
In these cases, the crescentic scar is elongate with the long axis parallel to the steep preexisting joint (Fig. 6A), rather than exactly perpendicular to ice flow (Fig. 5B, $n=40$ ). Thus, whilst the crescentic scars broadly indicate the direction of ice flow because all conchoidal fractures dip down-ice, the exact orientation is constrained by the orientation of the joints in the substrate, similar to that observed for joints and plucked faces in roche moutonnées (Hooyer et al., 2012).
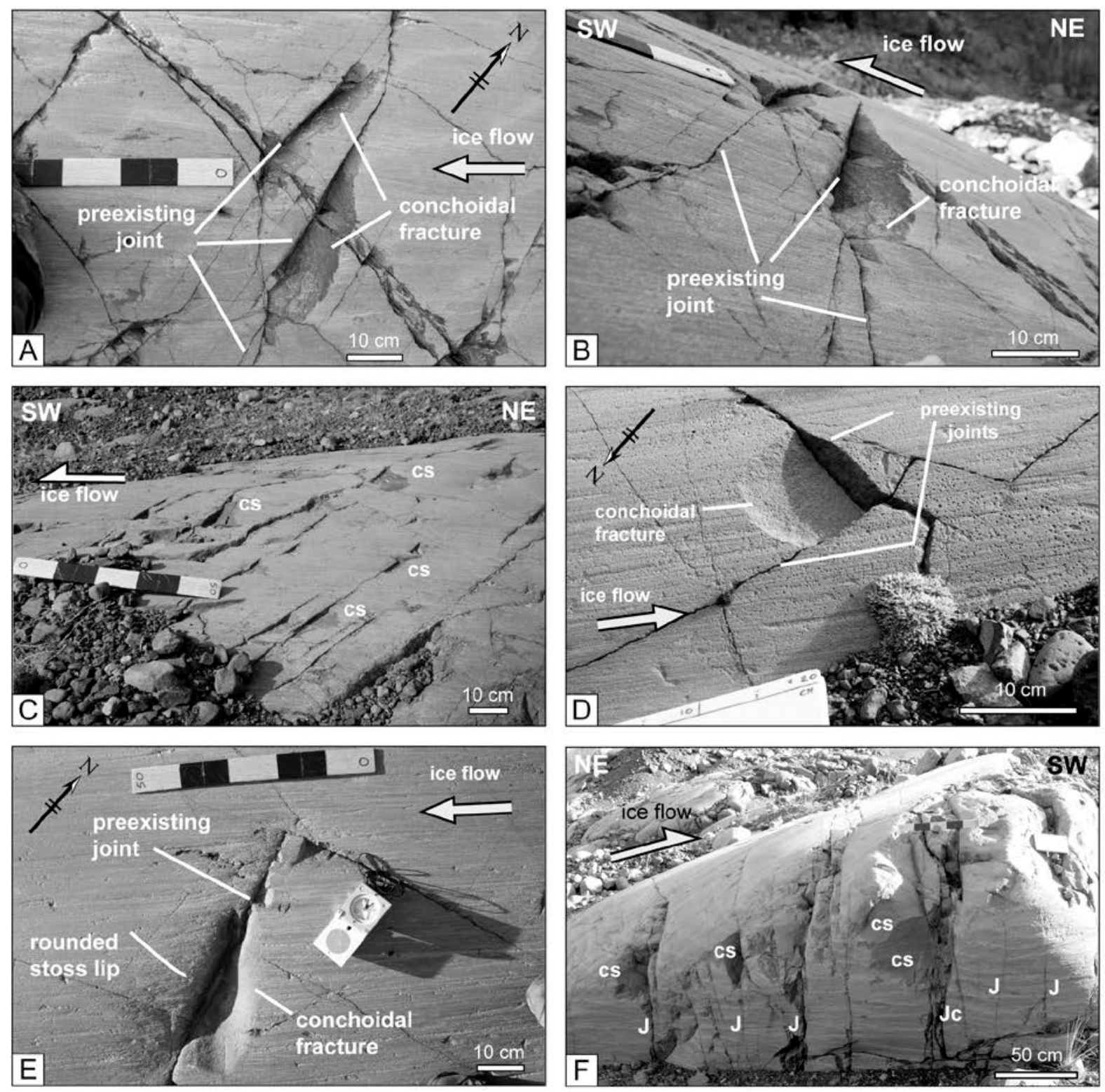

Fig. 6. Field photos of joint-bounded crescentic scars, Virkisjökull. All striations are part of the main set. Scale and ice flow directions indicated. $\mathbf{c s}=$ crescentic scar; $\mathbf{J}=$ joint. (A) Two joint-bounded crescentic scars, each bounded by single joint, elongate at high angles to ice flow; planview. (B) As previous, oblique view. (C) Planed surface with multiple crescentic scars, each bounded by single joint; joints are part of NNW-SSE joint set; oblique view. (D) Crescentic scar bound by two joints, part of columnar jointing set; oblique view. (E) Joint-bounded crescentic scar. Lip of joint and conchoidal fracture have been smoothed/abraded after scar formation; planview. (F) Roche moutonnée with set of crescentic scars on convex surface between lateral and top surface. Vertical joints cut entire bedform. Pale-dark striping is a magmatic flow banding; on the lateral surface this is approximately coincident with striations. 
A few crescentic scars are bounded by two subvertical, intersecting joints (related to columnar jointing) and are more equant in planview (Fig. 6D). Most joint-bounded crescentic scars have sharp edges and show little or no modification by subsequent abrasion. However, the edges of some scars have been modified by subsequent subglacial abrasion, with faint striae on the modified conchoidal fracture surface and significant edge rounding on the steep lip (Fig. 6E).
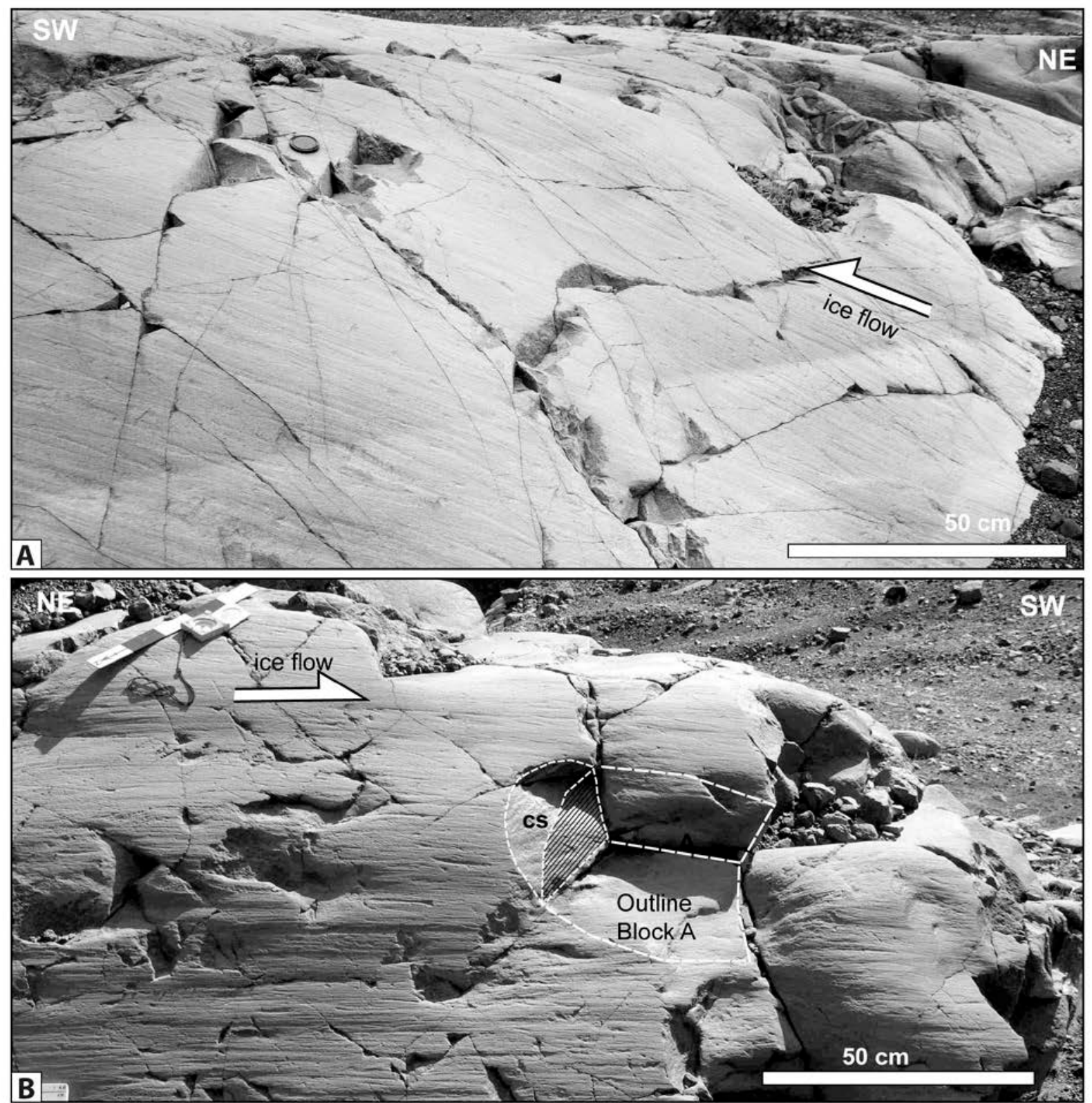

Fig. 7. (A) Joint-bounded crescentic scars on gently dipping stoss-side. All crescentic scars terminate against a preexisting joint; facing up-ice. These crescentic scars have the highest depth-to-width ratio of all scars observed. (B) Crescentic scar (cs) on top surface of roche moutonnée, close to lee side, showing potential interaction with plucking. Block A = interpreted outline of joint-bounded block removed by plucking. Hatched surface represents joint surface that may have formed the ice-facing bound to the crescentic scar, but the stoss side of block A.

On level surfaces, the scars are 2-10 cm deep, 2-70 cm long, and 1-18 cm wide (details in Table 2). The surface area of individual fractures varies widely from ca. 2 to $240 \mathrm{~cm}^{2}$ (interquartile range 8-48 $\mathrm{cm}^{2}$ ). However, in many cases a series of apparently overlapping conchoidal fractures has 
developed along the same joint (Figs. 3C, 6A, C), so that individual fractures are difficult to define. The angle of failure between the conchoidal fracture and the bedrock surfaces is between 10 and $25^{\circ}$.

One roche moutonnée contains a number of crescentic scars on the curved surface between its top surface and its lateral wall (Fig. 6F). The associated joints cut the entire roche moutonnée. At least one crescentic scar is composite and comprises two conchoidal fractures (right of centre on Fig. 6F). The associated joint is a composite, anastomosing set of narrowly spaced joints. These crescentic scars were the largest observed and have the smallest width/length ratio. The angle between the fracture and the bedrock was similar, about $20^{\circ}$.

A set of joint-bounded crescentic scars was observed on a gently dipping (ca. 10-20 ${ }^{\circ}$ ) stoss side of a whaleback (Fig. 7A). These scars are deeper (up to $20 \mathrm{~cm}$ and larger depth-to-width ratio) and have a greater angle (ca. $30-40^{\circ}$ ) between the fracture and the bedrock compared to those on level surfaces.

Close to the lee-side of a roche moutonnée, joint-bounded crescentic scars may interfere with lee-side plucking. Near the lee-side of one roche moutonnée, a crescentic scar was found adjacent to a block removed by plucking (Fig. 7B). If the crescentic scar formed prior to plucking (which we cannot prove) then the exposed joint surface (hatched on Fig. 7B) would have been a partial stoss-face of block A, against which ice could have pushed, thus aiding the block removal. Consequently, the occurrence of crescentic scars may aid subglacial erosion by plucking.

Importantly, crescentic fractures or crescentic gouges not associated with joints were not observed on the Virkisjökull outcrops.

\section{4..3 Joint-bounded crescentic scars, NW Scotland}

Joint-bounded crescentic scars were noted on outcrops of Lewisian gneiss at the Rispond headland, east of Durness on the north coast of mainland Scotland (Fig. 8A). This area has undergone repeated ice-sheet glaciation during the Pleistocene, and deglaciated between 15 and 20 ka (e.g., Stoker et al., 2009). Maximum ice thickness during the Last Glacial Maximum is uncertain in this region (cf. Ballantyne et al., 1998; Fabel et al., 2012) but was probably around $500 \mathrm{~m}$. The area shows a 'landscape of areal scour' or 'cnoc-and-lochan landscape' marked by abundant roches moutonnées, whalebacks, and enclosed basins, which are widely developed on Lewisian gneiss in NW Scotland (e.g., Rea and Evans, 1996; Bradwell, 2013; Krabbendam and Bradwell, 2014). Striae generally are poorly preserved on Lewisian gneiss because of post-glacial subaerial weathering, (Lawson, 1996; Bradwell, 2013). The bedrock on which the features occur is a coarse-grained (1-6 mm) quartzofeldspathic gneiss.

Joint-bounded crescentic scars were found on a well-defined symmetrical bedrock whaleback and on a level bedrock surface. The whaleback shows well-defined crescentic scars (Figs. 8B, C) alongside other more poorly defined and/or degraded examples. 

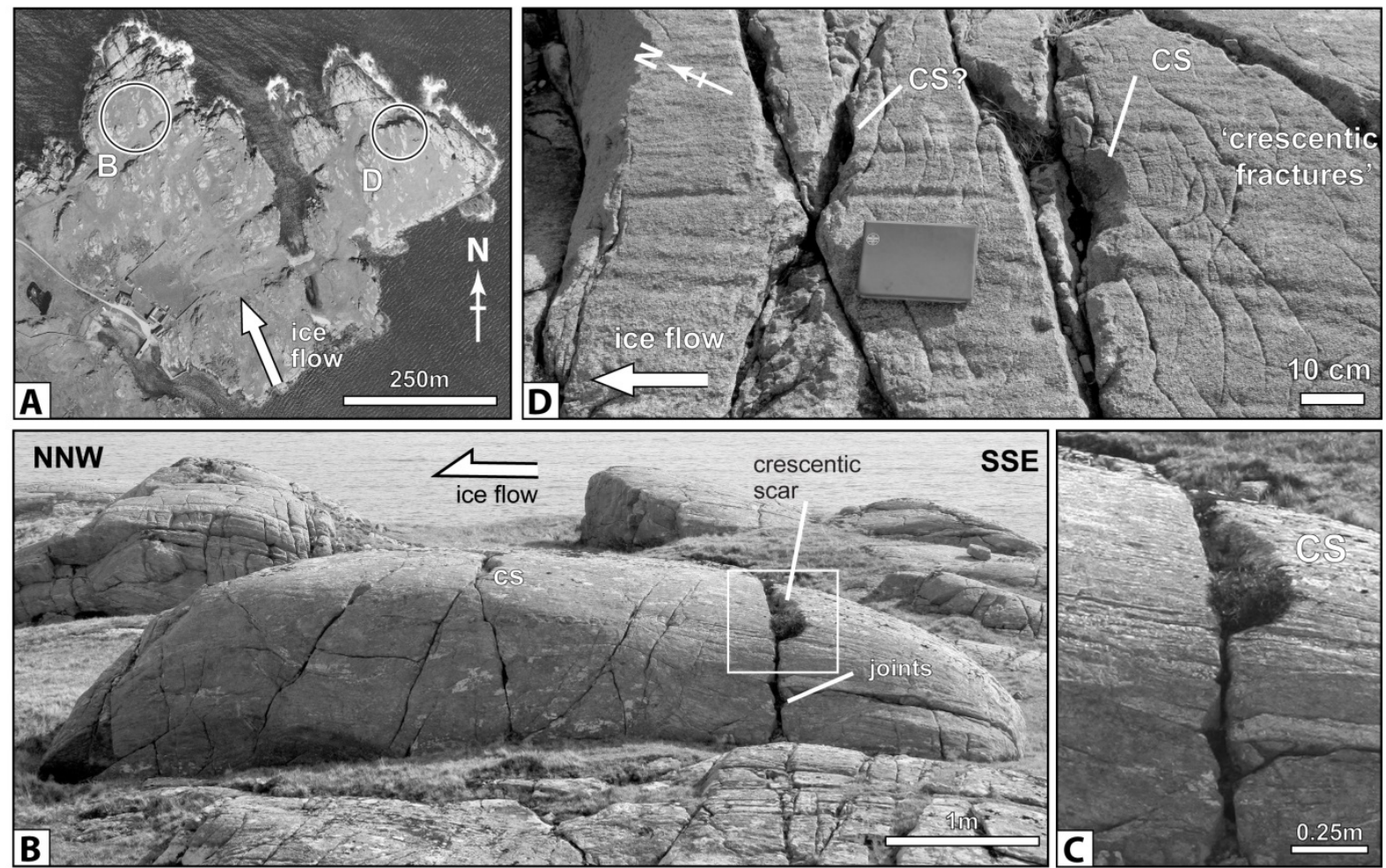

Fig. 8. (A) Airphoto of location of ice-worn outcrops of Lewisian gneiss, Rispond, NW Scotland. British National Grid (BNG) square NC 4565. Aerial photography (C) UKP/Getmapping Licence No. UKP2006/01. (B) Roche moutonnée with joints and crescentic scars (CS). Palaeo-ice flow indicated. BNG: NC 4515 6570. (C) Detail of (B). (D) Degraded crescentic scars on flat surface of gneiss. Note deep glacial striae and crescentic fractures. BNG: NC 45556569.

All crescentic scars terminate against well-defined, subvertical joints (0.3-1 m spacing) that cut the entire outcrop. Weakly preserved striae also occur locally (Fig. 8C). On the level surface (Fig. 8D), glacial striae are remarkably deep and well preserved despite post-glacial weathering and indicate palaeo-ice flow toward the NNW. The level surface shows more intense jointing; two sets of subvertical joints occur with angles ca. $40^{\circ}$ apart and with a joint spacing of ca. $10-30 \mathrm{~cm}$. One welldefined crescentic scar terminates against two joints (Fig. 8D, right of centre). Less well-defined (or degraded) crescentic scars occur nearby (Fig. 8D, to the left). Two large sets of overlapping crescentic fractures (without scars) occur right of the notebook, another set occurs above it; all are concave down-ice. The dip of the conchoidal fractures in both outcrops is ca. $35-40^{\circ}$.

\subsection{Joint-bounded crescentic scars, Ontario, Canada}

By analysing an extensive photo archive of bedrock features on the southern part of the Canadian Shield in Ontario, a number of joint-bounded crescentic scars were noted. All features were formed under the broadly southward flow of the last Laurentide Ice Sheet that deglaciated from the area ca. 10-12 ka before present (Prest, 1983; Dyke, 2004). A set of joint-bounded crescentic scars occur on metamorphosed turbidite (Huronian Supergroup, Palaeoproterozoic; Brocoum and Dalziel, 1974) near Sudbury, Ontario, Canada (Fig. 9A). The scars occur on a gently curved, smoothed, abraded, and pervasively striated surface, part of a larger whaleback or rock drumlin. The crescentic scars are 
invariably bound by subvertical joints that cut the entire outcrop. The long axes of the scars are at an angle of up to ca. $40^{\circ}$ to the striae and thus not always perpendicular to ice flow. Two crescentic scars occur at the junction of two joints (top-middle part of Fig. 9A) and are more equant than those developed along single joints. The bedrock is a finely bedded turbiditic sequence of metagreywacke and pelitic layers. These rocks are generally weaker than crystalline rocks (gneiss, granite) that occur widely up-ice across the Superior Province. Gneiss erratics occur throughout the area.

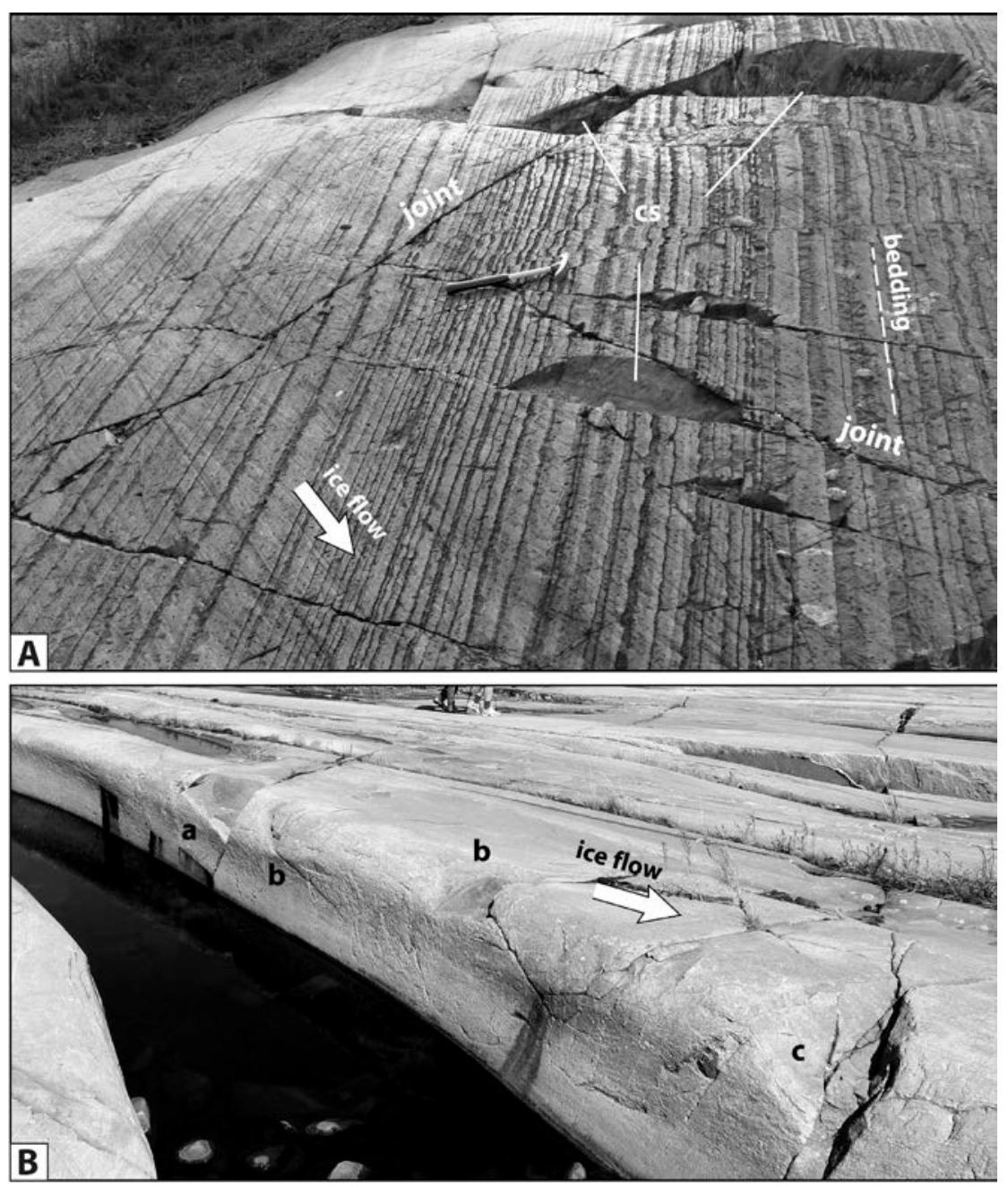

Fig. 9. (A) Joint-bounded crescentic scars on metamorphosed turbidite (Huronian Supergroup), near The Big Nickel, Sudbury, Ontario, Canada, $46^{\circ} 28^{\prime} \mathrm{N}, 81^{\circ} 02^{\prime} \mathrm{W}$. Hammer is ca. $40 \mathrm{~cm}$ long. (B) Joint-bounded crescentic scars, on the lateral crest of a groove-ridge pair, on granulite-facies gneiss, Painted Rocks, Georgian Bay, Ontario. Height of surface above water is ca. $80 \mathrm{~cm}$. Letters explained in text

On the NE shore of Georgian Bay, Lake Huron, an extensive peneplain, cut across massive and foliated gneisses and granulites of the ca. 1 Ga old Grenville Province (Easton, 1992), has been subjected to extensive glacial erosion, resulting in the formation of highly elongate rock drumlins and parallel megagrooves (e.g., Krabbendam et al., 2016), superposed on which are abundant bedforms such as sinuous grooves formed by subglacial erosion by sediment-laden meltwaters moving through interlinked ice cavities (Kor et al., 1991). On the lateral crest of a groove-ridge, a number of jointbounded crescentic scars occur (Fig. 9B), with different morphologies depending on their relation to the parent joint. A steep scar (ca. $20 \mathrm{~cm}$ deep and $70 \mathrm{~cm}$ wide) developed on a single sub-vertical joint (a 
on Fig. 9B). More shallow-dipping scars (b) developed on joints that dip down-ice, whereas scar (c) is a deep, composite feature developed on a set of closely spaced joints. Very large erratics (up to $4 \mathrm{~m}$ across) of the same rock type occur nearby, and sets of crescentic fractures were also noted.

\section{Discussion}

The occurrence of joint-bounded crescentic scars raises two main questions: (i) how are conchoidal fractures on bedrock surfaces generated subglacially, and (ii) what is the exact role of the preexisting joints. Previous work suggests that subglacial conchoidal fractures are formed by high clast-bed contact forces (Gilbert, 1906; Harris, 1943; Hallet 1979; Ficker et al., 1980; Wintges, 1985; Drewry, 1986). This is corroborated by work on conchoidal fracturing as a typical failure mode of a range of brittle materials (glass, ceramics, flint, dental materials) by an applied focused contact force, usually by some form of indenter (e.g., Smith, 1984; Cotterell et al., 1985; Lawn, 1998; Roberts, 2000; Geng et al., 2010). Relevant also is the work done on conchoidal fracturing close to an edge, termed edge flaking or edge-chipping in the engineering literature (e.g., Almond and McCormick, 1986; Chai and Lawn, 2007a, b; Quinn and Mohan, 2009; Zaayman et al., 2009).

In the following section we discuss five aspects of joint-bounded crescentic scars: (i) the order of magnitude of the forces required for conchoidal fracturing to occur; (ii) how these forces can be generated; (iii) the role of preexisting joints in weakening the rock so that failure occurs; (iv) their formation mechanism; and (v) implications for bedrock failure on the glacier bed in general.

\subsection{Forces required}

The tensile strength and shear strength of rhyolite lies in the order of 5-15 and 10-50 MPa respectively (Table 1; using microgranite as nearest proxy). The surface area of the conchoidal fractures found in this study ranges between ca. 5 and $50 \mathrm{~cm}^{2}$ (Table 2). This implies that clast-bed contact forces in the order of 2.5-2500 kN were needed to form conchoidal fractures of that size. Clast-bed contact forces can also be estimated using the surface area of small pits on the stoss side (ca. 10-60 mm²; see section 4.1 and Fig. 4C), which are likely formed by large clasts pressing onto and being crushed against the bedrock, multiplied by the compressive strength of the bedrock (50-200 MPa; see Table 1). This is analogous to the clast-bed contact force estimation using the width of striae as proposed by Hallet (1979). This would suggest clast-bed contact forces in the order of 0.5-18 kN. The resulting values have a very wide range, and it may be better to suggest an increasing probability of fracturing as clastbed contact forces increase from the low to the high end of these ranges (Fig. 10A).

\subsection{Generation of clast-bed contact forces}

The focussed forces on the bedrock surface are generated by clasts pressing onto the glacier bed. The generation of these clast-bed contact forces, however, is nontrivial and has been long debated (e.g., Boulton, 1974; Hallet, 1979, 1981; Cohen et al., 2005; Byers et al., 2012). It comprises several 
components (Fig. 10), all a function of the radius of the clast, which in this section is assumed to be spherical.

- $\quad F_{b}$ is the buoyant weight of a rock clast embedded in ice (Fig. 10B), and is a function of the density and volume of the rock clast, and is significant only for large (>0.5-1 m) clasts (e.g., Hallet 1979; Cohen et al., 2005). The formulation of this component is straightforward (Hallet, 1979):

$F_{b}=\left(\rho_{r}-\rho_{i}\right) g 4 / 3 \pi R_{c}^{3}$

where $\rho_{r}$ and $\rho_{i}$ is the density of rock and ice respectively, $g$ is the gravitational constant, and $R_{c}$ is the radius of the clast. The contribution of the buoyant weight, however, is small and is not likely to result in fracturing (curve A on Fig. 10A).

- More debatable is the force $F_{e}$ generated by the effective pressure of ice acting on the clast, which would imply that the clast-bed contact force is indirectly dependent on the thickness of the overlying ice. Boulton (1974) regarded this as the dominant force, whereas Hallet (1979) argued this force was negligible, because if ice surrounds the clast, the pressure would act equally on all sides (see discussion in Benn and Evans, 1998). However, if a water film occurs between the ice and the bed so that ice does not completely surround the clast (Fig. 10C), the clast-bed contact force by effective pressure can be described by (e.g., Cohen et al., 2005):

$F_{e}=\pi\left(P_{i}-P_{w}\right)\left(2 h_{w} R_{c}-h_{w}{ }^{2}\right)$

where $P_{i}$ is the cryostatic pressure, $P_{w}$ is the water pressure, and $h_{w}$ is the thickness of the water film. As the water film is generally thought to be thin $(<1 \mathrm{~mm})$, the contribution of this force is very small and can in practice be ignored (curves B on Fig. 10A). However, if a cavity develops behind a clast, even less ice surrounds the clast (Fig. 10D), and the resultant clast-bed contact force may be described as (Cohen et al., 2005):

$F_{e}=0.5 \pi\left(P_{i}-P_{w}\right)\left(R_{c}{ }^{2}+2 h_{w} R_{c}-h_{w}{ }^{2}\right)$

In that case, the clast-bed contact force becomes very high and can reach 40-70 kN with relatively small clasts (curve C on Fig. 10A). Cavity formation may be encouraged by strongly fluctuating water pressures (e.g., Bindschadler, 1983). The highly variable meltwater discharge from Virkisjökull, the proglacial and historic evidence for jökulhlaups, and evidence for vigorous subglacial meltwater erosion (Section 3) suggest that periodically high water pressures are a possibility. However, whether cavities behind such clasts actually develop in nature is uncertain.

- A viscous drag force $F_{d}$ is exerted by ice on the clast as ice flows downward toward the base owing to basal melting (Fig. 10E). It is a function of the viscosity of ice and the vertical velocity of ice $V_{i z}$ toward the bed. This vertical velocity will in most cases equate to the basal melt rate. Below is a simple formulation for larger clasts, where the drag force is dominated by viscous flow rather than regelation (Hallet, 1979; see also Cohen et al., 2005, for a more involved formulation):

$F_{\mathrm{dz}}=4 \pi V_{i z} \eta R_{c}$

where $V_{i z}$ is the vertical velocity of ice and $\eta$ the ice viscosity. The viscous drag force appears to be the dominant component of the clast-bed contact force, certainly for smaller clasts (Hallet 1979; 
Cohen et al., 2005; Byers et al., 2012). In experiments with an artificial clast $\left(R_{c}=2.5 \mathrm{~cm}\right)$ pressing onto a bed under high basal melting rates, Byers et al. (2012) reached clast-bed contact forces between ca. 1 and $2 \mathrm{kN}$, some four orders of magnitude higher than the buoyant weight of a clast of rock of that size (c. $0.12 \mathrm{~N}$ ), and attributed these forces mainly to viscous drag. If these values are extrapolated to larger clast sizes, while assuming $F_{d z} \propto R_{c}$ (according to Eq. 4), then clast-bed contact forces $>40 \mathrm{kN}$ appear possible with clast radii between 0.5 and $1 \mathrm{~m}$ (lines B on Fig. 10A).
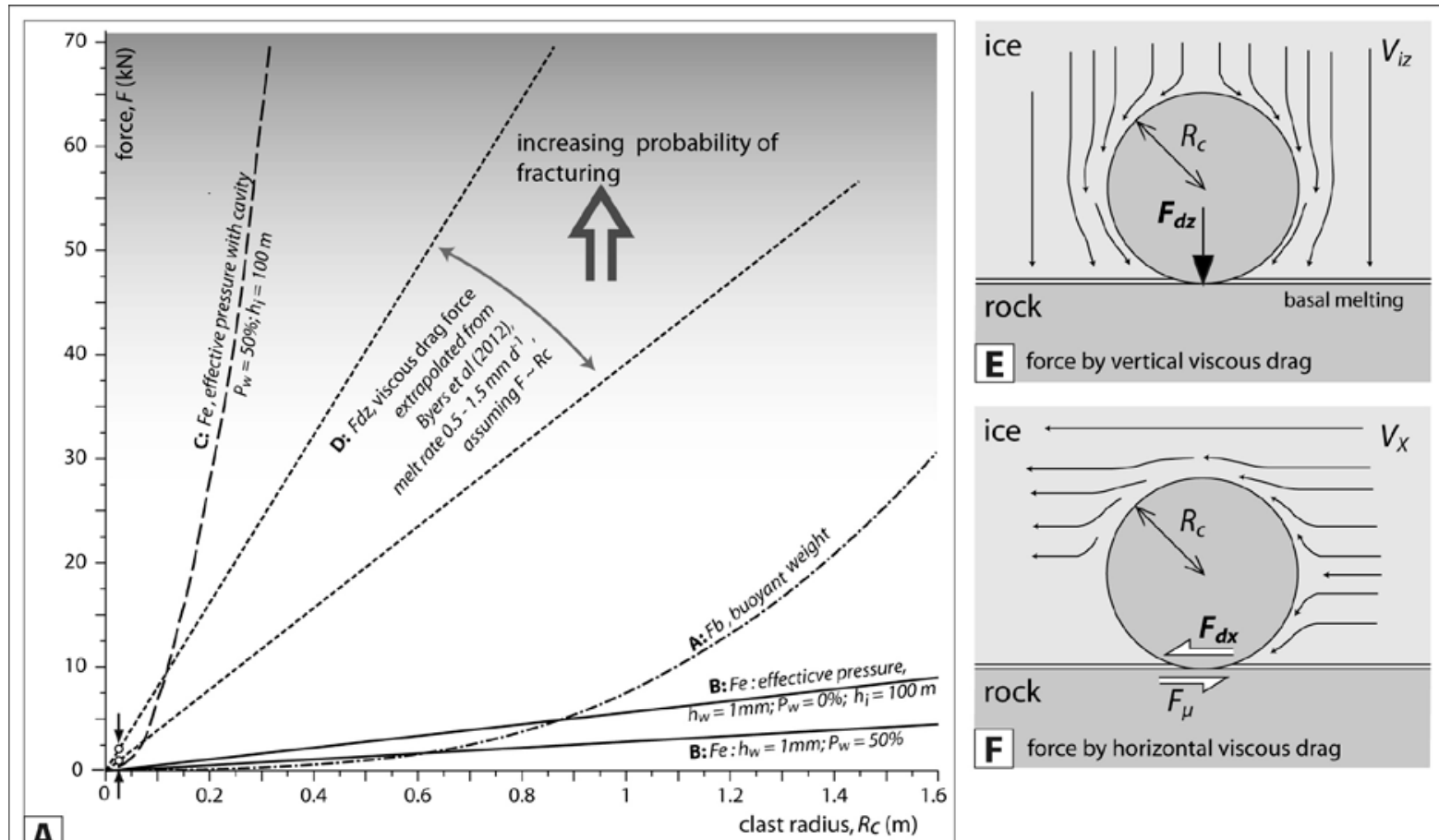

A clast radius, $R c(\mathrm{~m})$
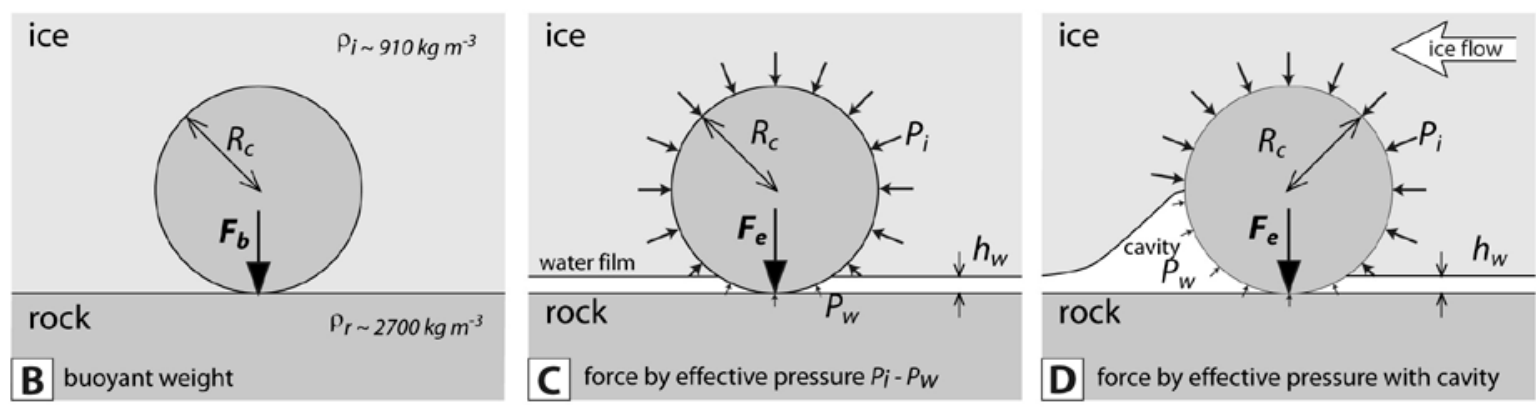

Fig. 10. Clast-bed contact forces. (A) Plot of clast-bed contact force $F$ against clast radius $R_{c}$, for different force components. Lines A, B, C are curves of Eqs. (1), (2), (3), respectively (see text); lines D represent the range of values extrapolated from experiments by Byers et al. (2012) (small arrows), interpreted as mainly caused by viscous drag $F_{d z}$. (B) Force $F_{b}$, buoyant weight. (C) Force caused by effective pressure $F_{e}$. (D) Force caused by effective pressure $F_{e}$, in the presence of a cavity. (E) Force caused by vertical viscous drag $F_{d z}$. (F) Force caused by horizontal viscous drag $F_{d x}$, balanced by dynamic friction force $F$

On a level bedrock glacier bed, all the above forces act vertically on the bed and would not result in crescentic bedforms with a consistent asymmetry. Such consistent asymmetry requires an oblique force with a horizontal component. On a level subglacial surface, only viscous drag force can have a horizontal component $\left(F_{d x}\right)$ caused by subhorizontal ice flow around the clast (Fig. 10F). This occurs because the clast is subjected to rock-on-rock friction as it slides over the bed so that the clast moves 
slower than the ice around it. The horizontal drag force is then limited by the dynamic friction $F_{\mu}$ between the clast and the bedrock (Fig. 10F), with a rock-rock friction coefficient (e.g., Drewry, 1986; Cohen et al., 2005). The strong asymmetry of joint-bounded crescentic scars in this study (and in previously reported other crescentic markings), suggests that viscous drag with its crucial horizontal component $F_{d x}$ is the most important force component to consider, although the possibility remains that effective pressure with cavitation plays a role if rapidly fluctuating water pressures occur. Estimates of subglacial parameters such as the viscosity of ice, the basal melting rate and the thickness of the water film remain highly uncertain so that exact quantification of the forces is not possible. Nevertheless, it follows that sufficiently high clast-bed forces are favoured by (i) large, boulder-size (>0.5-1 m) clasts; (ii) high basal melting rates; and (iii) possibly strongly fluctuating water pressures.

\subsection{Limits on clast-bed contact force by the strength of the clast}

The magnitude of the clast-bed contact force is limited by the strength of the clast itself (e.g., Hallet, 1979); so that fracturing depends to a degree on the relative strengths of the clast and the bed. Consider a clast of rock moving under force over a bedrock substrate, with a force balance at the clast-bed contact; further assume that the contact force is sufficient to cause fracturing of either the bed or the clast. A clast of weak rock (Fig. 11A) will itself fracture and disintegrate before any crescentic markings can develop on the bed. In contrast, a clast of a strong rock moving over a weaker substrate can fracture the bed and cause crescentic markings (Fig. 11B); this is similar to the experiment of Smith (1984), who rolled a steel ball under force over a glass substrate. Returning to our Schmidt Hammer observations from Iceland, this would imply that a hard and strong basalt clast moving over a (slightly) less hard and weaker rhyolite substrate (see section 4.1 and Table 1) would be capable of creating crescentic markings. The same would be the case for a gneiss clast over a bed of sedimentary rock, as near Sudbury, Ontario. Conversely, a clast of sandstone moving over a substrate of gneiss is unlikely to create crescentic markings on the bed.

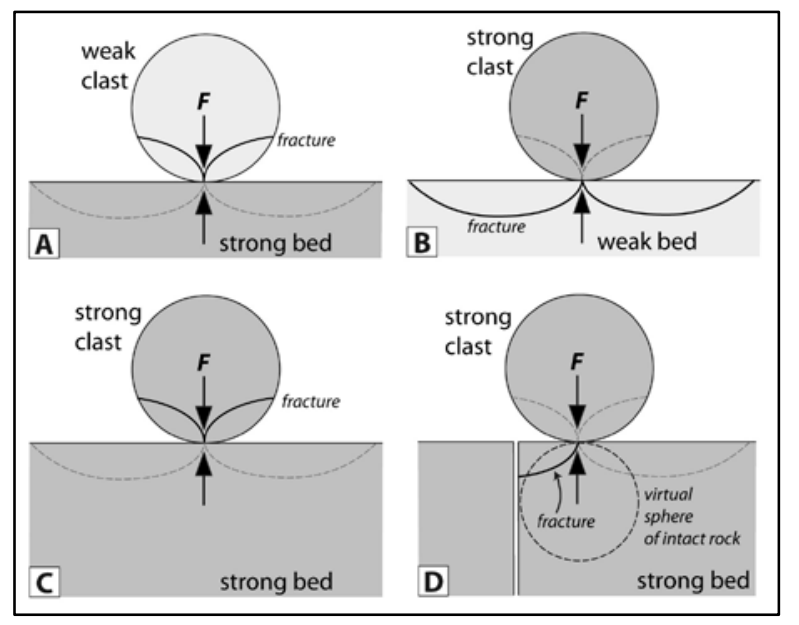

Fig. 11. Clast versus bed strength, and potential failure. (A) Weak clast forced onto strong bed. (B) Strong clast forced onto weak bed. (C) Clast and bed of equal strength. (D) Clast and bed of equal strength, with join

Now consider a clast, moving under force over a glacier bed of the same lithology, for example a rhyolite clast over a rhyolite bed or a gneiss clast over a gneiss bed (Fig. 11C). In that case the area of 
potential fracture of the clast (related to the volume of intact rock) is smaller than that in the bed so that the stresses in the clasts are higher than in the bed: the clast would fracture and not the bed. In reality, the strength of bedrock will always show variations, for example owing to small variations in grain size or composition or incipient, variable weathering of the bedrock. Thus, if a number of clasts move under force over a bed of the same lithology, it is possible that some clasts are stronger than some patches of the bed.

The assumptions above all hold only if the bed and the clast have no preexisting joints. Joints in large clasts are not likely — such a clast would disintegrate into smaller clasts. If, however, the bed contains joints across which stresses cannot be freely transferred, then a particular clast-bed contact force may lead to stress concentrations in the bed that exceed those within the clast. One way of viewing this is by envisaging a virtual sphere of intact rock within the bed, bound by its top surface and the joint (Fig. 11D): if this virtual sphere of intact rock is smaller than the clast, then the area of potential fracture in the bed is smaller, and the resultant stresses higher. In that case, the bed rather than the clast may fracture, leading to the formation of joint-bounded crescentic scars, as further explored below.

\subsection{Role of free edges, joints, and oblique forces in conchoidal fracturing}

From the engineering literature, it is known that if a focussed contact force (point load) is applied perpendicularly onto a flat surface, the resulting stress field in the substrate, known as a Hertzian contact stress, is symmetrical (e.g., Lawn, 1998). The exact geometry of the stress field and the principal stress trajectories depends on the force, the area of contact, and the elastic properties (Poisson's ratio and Young’s modulus) of the materials involved (e.g., Lawn, 1998; Roberts, 2000). Directly below the contact point is a region of compressive stress (Fig. 12A) (exerted by a hard indenter rather than a clast in engineering experiments); whilst close to the surface, the stress is tensile (Lawn, 1998; Roberts 2000). It is this tensile stress that leads to fracturing if it exceeds the tensile strength of the material. For a symmetrical stress field, the resulting fracture would be circular on the surface. To our knowledge, only one such subglacially formed circular scar has been reported to date (a circular annular scar on granite in the Sierra Nevada, USA, by Gilbert, 1906), suggesting symmetrical Hertzian contact fracturing is rare in natural subglacial beds. However, if the point load is oblique (Fig. 12B), the stress field becomes asymmetric (e.g., Ficker et al., 1980; Geng et al., 2010). These oblique loads produce the previously reported asymmetric crescentic markings (e.g., Gilbert 1906; Ficker et al., 1980).

If a clast-bed contact force is exerted close to an edge (a free face), the stress field in the bed is further distorted and becomes highly asymmetric (see Fig. 12C). We suggest that a joint in bedrock on the glacier bed can be regarded as a semifree edge, across which stresses cannot freely be transferred, so that the stress fields adjacent to a joint in bedrock and those along free edges in engineering tests are comparable (Fig. 12C). Engineering tests on such edge flaking with different materials (glass, porcelain, alumina, and zirconia) have shown that: 
- $\quad$ higher contact forces and tougher materials create larger flakes (Hangl et al., 1997; Chai and Lawn, 2007a);

- $\quad$ the critical force $F$ required for failure increases with distance $d$ from the edge (Fig. 12C), according to $F \propto d^{3 / 2}$ (Chai and Lawn, 2007a); in other words, as a contact force migrates toward an edge, the force of failure decreases rapidly;

- the stress field is highly asymmetric, with very high stress concentrations building up between the indenter and the edge (Zaayman et al., 2009);

- $\quad$ an oblique rather than a perpendicular contact force close to an edge (as occurs on glacial beds caused by the horizontal viscous drag force component, see section 5.2) lowers the contact force required for failure even further: a deviation of c. $15^{\circ}$ from the perpendicular halved the critical load (Chai and Lawn, 2007b); and

- $\quad$ flakes are shallower with increasing obliquity of the load (Quinn and Mohan, 2009).

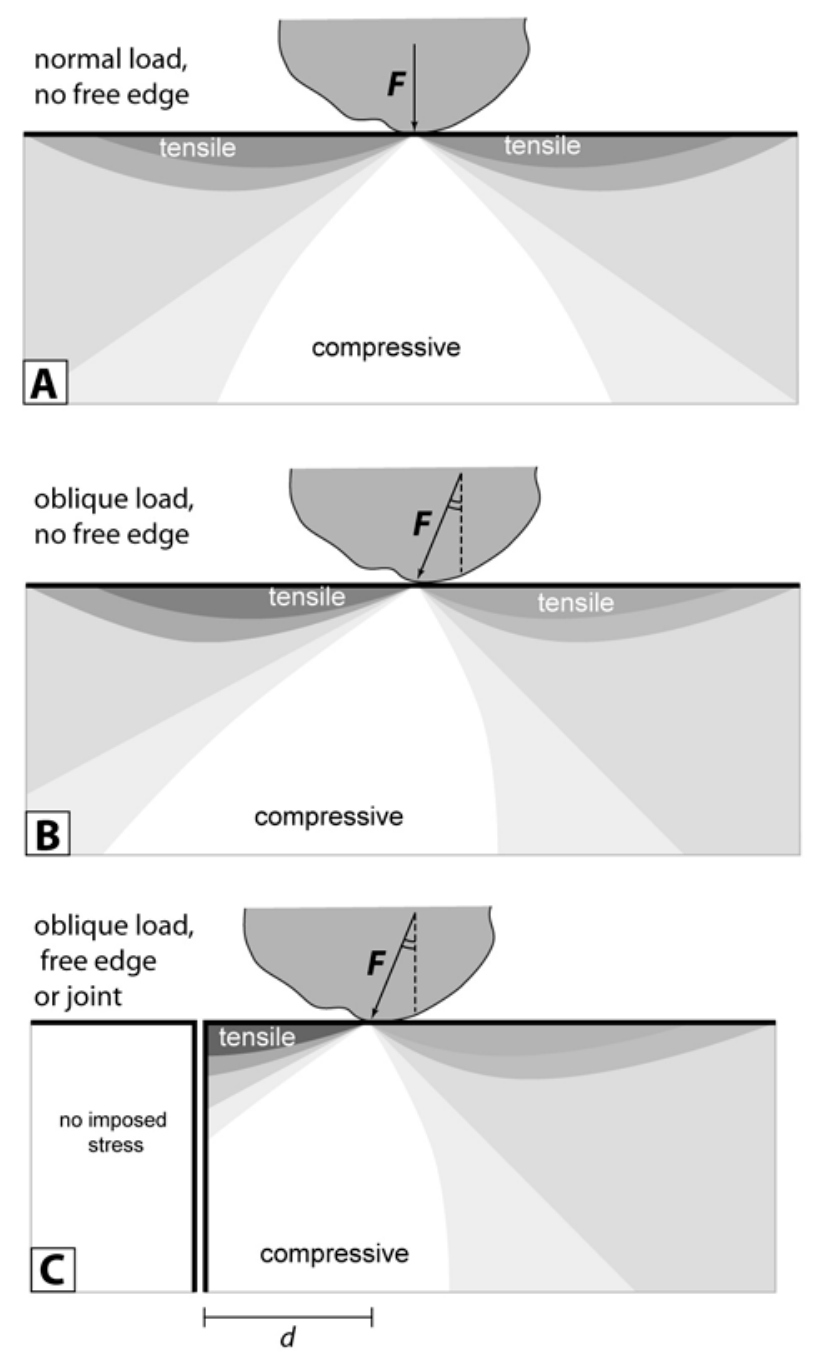

Fig. 12. Schematic diagram showing stress fields with zones of compressive and tensile stress. (A) Normal load, no free edge, classic symmetrical Hertzian contact stress (see Roberts, 2000); (B) oblique load, no free edge; (C) oblique load, close to free edge or joint. Stress concentrations schematically indicated using shading. It is assumed no stresses are transferred across the joint.

\subsection{Formation mechanism}


Previously reported crescentic gouges and lunate fractures do not interact with preexisting joints; the secondary fracture is the result of a rock fragment breaking off (Fig. 1A, B). In the joint-bounded crescentic scars reported here, the conchoidal fracture invariably stops against a preexisting joint, whereby these joints play the role of a semifree edge.
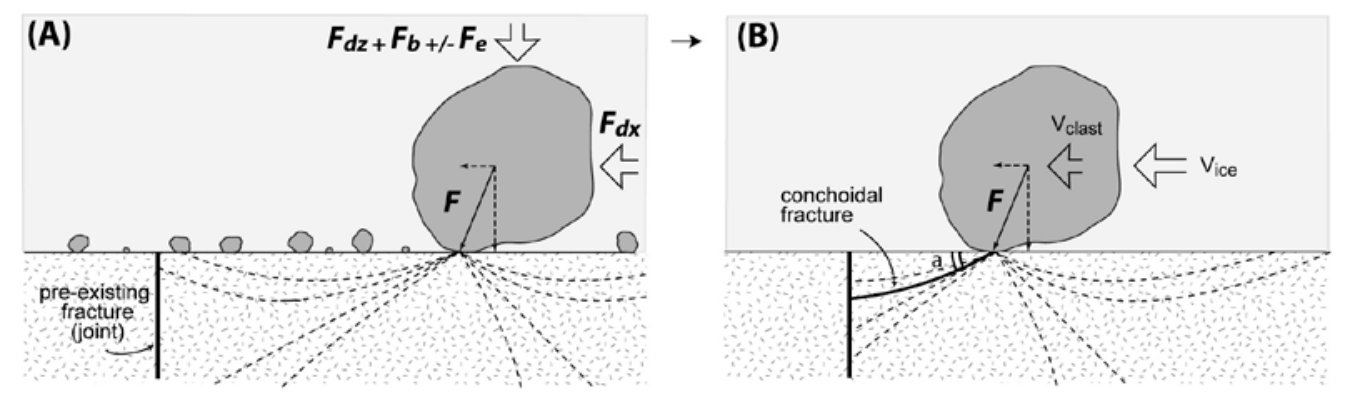

Joint-controlled conchoidal fracturing
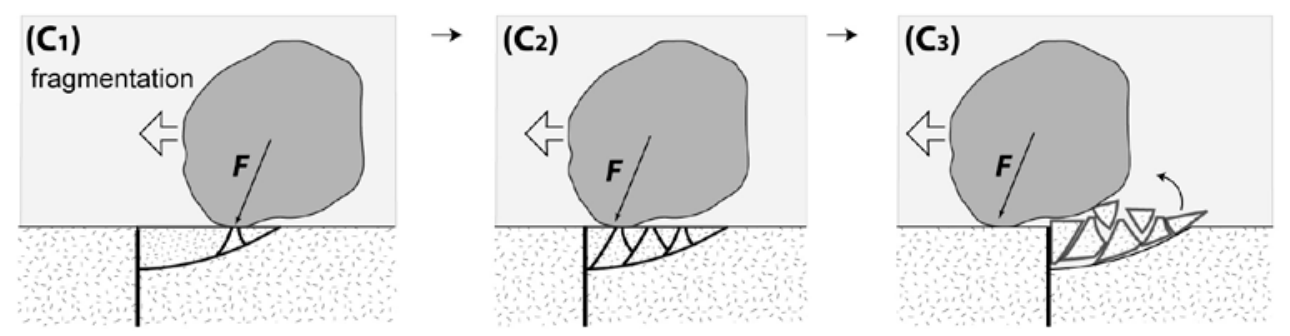

model for removal of fragment

Fig. 13. Schematic diagram illustrating suggested mode of formation of joint-bounded crescentic scars. (A) Boulder embedded in basal ice causes stress field in bed, insufficient for fracturing; (B) as boulder approaches bedrock joint, stresses in bedrock increase and conchoidal fracturing occurs; (C) rock fragment is further fragmented or crushed; loose fragments are removed from crescentic scar.

We suggest the following formation mechanism for joint-bounded crescentic scars on subglacial rock surfaces (Fig. 13):

- A boulder-size clast entrained in ice at the base of a glacier or ice sheet exerts a clast-bed contact force as it moves across the underlying bedrock surface. This force is oblique, owing to horizontal viscous drag and clast-bed friction, which creates an asymmetric stress field within the bedrock. The stresses within the bedrock may be high, but not necessarily high enough to produce crescentic markings away from joints (Fig. 13A).

- As the clast, and with it the stress field within the bed, migrates and approaches a subvertical joint, the stresses in the bed cannot transfer across the joint. Stress concentrations build up between the clast-bed contact point and the joint; if these stresses exceed the intact tensile rock strength, the rock fails and a new conchoidal fracture forms, delineating a wedge-shaped rock fragment (Fig. 13B).

- The rock fragment, bounded by the preexisting joint and the new conchoidal fracture, is removed from the bedrock, leaving a crescentic scar. No direct evidence is available regarding the exact removal mechanism of the loose fragment, but a likely possibility is that as the boulder moves over the fragment, the fragment is further fractured or even crushed (comminution; Fig. 13C). 
This fracturing, whatever its exact form, will expose smaller fragments to direct ice flow and the multiple fragments will be evacuated out of the scar.

\subsection{Summary of implications and significance}

The joint-bounded crescentic scars found and described in this study represent a new glacial erosional bedform. The crescentic scars may lead to a minor roughening of smooth surfaces and may also aid glacial erosion by plucking. More crescentic scars will likely be recognised in the future, as we believe they are relatively common. Nevertheless, the contribution of these features to overall subglacial erosion is likely to be minor. Instead, the significance of the joint-bounded crescentic scars lies in the information it provides about the behaviour of bedrock in the subglacial environment and about the size and strength of the subglacially embedded material.

The joint-bounded crescentic scars described herein imply that it is very difficult (if not impossible) to fracture intact rock by overriding ice pressure alone; some form of focussed clast-bed contact force applied by an embedded boulder is required to build up sufficiently high stresses in the bedrock bed. The formation mechanism is similar to that proposed for other crescentic markings, in that it involves a migrating contact stress field exerted by a moving boulder across a bedrock surface (Gilbert, 1906; Smith, 1984). However, the preexisting joints as observed in the rhyolite and gneiss clearly represent a weakness; in these circumstances much higher stresses can build up in the bed and conchoidal fracturing can occur at lower contact forces. In SE Iceland, contact forces were clearly never high enough to produce crescentic markings without preexisting joints, although they do occur locally in NW Scotland and Ontario. The formation of joint-bounded crescentic scars (and likely other crescentic markings as well) requires large boulders ( $>0.5-1 \mathrm{~m}$ across) so that the occurrence of crescentic scars also points to the (former) presence of boulder-size subglacial clasts. High basal melt rates, creating strong vertical viscous drag toward the base, is a further likely requirement — which may imply crescentic markings are generally formed during deglaciation or periods of relatively fast ice flow. The sharp edges of the crescentic scars near to joints suggest little modification by subsequent erosion, consistent with this explanation.

The findings of this paper can be used to improve design of experimental testing of clast-bed forces that are seen to be crucial to better constrain subglacial erosion as well as basal sliding (e.g., Byers et al., 2012; Zoet et al., 2013). Furthermore, these findings confirm the importance of preexisting joints as a major constraint on the efficacy of subglacial erosion, previously proposed by others specifically for plucking (Dühnforth et al., 2010; Krabbendam and Glasser, 2011; Hooyer et al., 2012). Combined, this suggests that numerical modelling of glacial erosion (as for instance attempted by Hildes et al., 2004; MacGregor et al., 2009; Iverson, 2012; Melanson et al., 2013) requires realistic characterisation of bedrock below glaciers, including the preexisting fracture patterns. 


\section{Conclusions}

Joint-bounded crescentic scars, as defined in this study, occur on glaciated bedrock surfaces, and comprise a concave conchoidal fracture dipping in the ice-flow direction and a steep fracture coincident with a preexisting joint. We have identified joint-bounded crescentic scars on a variety of rock types (fine-grained rhyolite, coarse-grained gneiss, metasedimentary rocks) and in a variety of settings (e.g., small outlet glacier and ice-sheet bed) and in contemporary (SE Iceland) and Pleistocene glacial environments (NW Scotland, and SE Canada). We suggest that they are formed by high clastbed contact forces applied by boulders embedded in basal ice moving over bedrock. As the subglacially embedded boulder approaches a subvertical joint, the stress field within the bedrock changes, and high stress concentrations build up between the clast-bed contact point and the joint. If these stresses are high enough, conchoidal fracturing results. Subsequent removal of the wedgeshaped rock fragment probably involves further fracturing or crushing (comminution) under high contact forces.

Our work in a variety of glacial settings suggests that joint-bounded crescentic scars are significant small-scale glacial bedforms for three reasons:

- In common with other crescentic markings, they are more robust ice-flow indicators than glacial striae, which are removed by only require a few millimetres of post-glacial weathering. However, the orientation of joint-bounded crescentic scars may be strongly influenced by preexisting joint orientation, so that they only indicate approximate ice flow orientation.

- Joint-bounded crescentic scars attest to the former presence of large boulders at the base of the ice mass, giving information about the character of subglacial debris in former glacial regimes and environments.

- $\quad$ Analysis of these bedforms shows that failure of intact bedrock is very difficult, if not impossible, in hard bedrock and emphasises the importance of preexisting joints in bedrock for glacial erosion mechanisms. Consequently, numerical modelling of glacial erosion require some characterisation of bedrock fracture patterns to capture the full range of subglacial erosion processes.

\section{Acknowledgements}

The observations in Iceland were made as part of the British Geological Survey’s Virkisjökull Observatory Project. Steve Roberts and Paul Warren are thanked for enlightening discussions on Hertzian fracturing and edge flaking. Sam Roberson is thanked for comments on an earlier manuscript. The comments of four anonymous reviewers are acknowledged and improved the manuscript. The authors MK and JE publish with permission of the Director of the British Geological Survey (Natural Environment Research Council). NE thanks the Natural Science and Engineering Council of Canada for support. 


\section{References}

Adebayo, B., Opafunso, Z.O., Akande, J.M., 2010. Drillability and strength characteristics of selected rocks in Nigeria. AU Journal of Technology 14, 56-60.

Almond, E., McCormick, N., 1986. Constant-geometry edge-flaking of brittle materials. Nature 321, 53-55.

Aydin, A., Basu, A., 2005. The Schmidt hammer in rock material characterization. Engineering Geology 81, 1-14.

Ballantyne, C.K., McCarroll, D., Nesje, A., Dahl, S.O., Stone, J.O., 1998. The last ice sheet in North-West Scotland; reconstruction and implications. Quaternary Science Reviews 17, 1149-1184.

Benn, D.I., Evans, D.J.A., 1998. Glaciers and glaciation. Arnold, London.

Bindschadler, R., 1983. The importance of pressurized subglacial water in separation and sliding at the glacier bed. Journal of Glaciology 29, 3-19.

Boulton, G.S., 1974. Processes and patterns of glacial erosion. In: Coates, D.R. (Ed.), Glacial Geomorphology. University of New York, Binghampton, 41-87.

Bradwell, T., 2013. Identifying palaeo-ice-stream tributaries on hard beds: Mapping glacial bedforms and erosion zones in NW Scotland. Geomorphology 201, 397-414.

Bradwell, T., Sigurđsson, O., Everest, J., 2013. Recent, very rapid retreat of a temperate glacier in SE Iceland. Boreas 42, 959-973.

Brocoum, S.J., Dalziel, I.W., 1974. The Sudbury Basin, the Southern Province, the Grenville Front, and the Penokean Orogeny. Geological Society of America Bulletin 85, 1571-1580.

Byers, J., Cohen, D., Iverson, N.R., 2012. Subglacial clast/bed contact forces. Journal of Glaciology 58, 89-98.

Cardozo, N., Allmendinger, R.W., 2013. Spherical projections with OSXStereonet. Computers \& Geosciences 51, 193-205.

Chai, H., Lawn, B., 2007a. A universal relation for edge chipping from sharp contacts in brittle materials: A simple means of toughness evaluation. Acta Materialia 55, 2555-2561.

Chai, H., Lawn, B., 2007b. Edge chipping of brittle materials: effect of side-wall inclination and loading angle. International Journal of Fracture 145, 159-165.

Chamberlin, T., 1888. The rock-scorings of the great ice invasions, US Geological Survey, Annual Report. 7, 155248.

Cohen, D., Iverson, N.R., Hooyer, T.S., Fischer, U.H., Jackson, M., Moore, P.L., 2005. Debris-bed friction of hard-bedded glaciers. Journal of Geophysical Research: Earth Surface 110, F02007.

Cotterell, B., Kamminga, J., Dickson, F.P., 1985. The essential mechanics of conchoidal flaking. International Journal of Fracture 29, 205-221.

Davis, G.H., Reynolds, S.J., 1996. Structural geology of rocks and regions. John Wiley, New York.

Din, F., Rafiq, M., 1997. Correlation between compressive strength and tensile strength/index strength of some rocks of North-West Frontier Province (limestone and granite). Geological Bulletin, University of Peshawar 30, 183.

Dreimanis, A., 1953. Studies of friction cracks along shores of Cirrus Lake and Kasakokwog Lake, Ontario. American Journal of Science 251, 769-783.

Drewry, D., 1986. Glacial geologic processes. Edward Arnold, London.

Dühnforth, M., Anderson, R.S., Ward, D., Stock, G., 2010. Bedrock fracture control of glacial erosion processes and rates. Geology 38, 423-426.

Dyke, A.S., 2004. An outline of North American deglaciation with emphasis on central and northern Canada. In: Ehlers, J., Gibbard, P. (Eds.), Quaternary Glaciations-Extent and Chronology, Part II: North America. Developments in Quaternary Sciences, 373-424.

Easton, R.M., 1992. The Grenville Province and the Proterozoic history of central and southern Ontario. In: Williams, H.R., Sutcliffe, R.H., Stott, G.M. (Eds.), Geology of Ontario. Ontario Geological Survey, 715904.

Embleton, C., King, C., 1975. Glacial geomorphology. Edward Arnold, London.

Fabel, D., Ballantyne, C., Xu, S., 2012. Trimlines, blockfields, mountain-top erratics and the vertical dimensions of the last British-Irish Ice Sheet in NW Scotland. Quaternary Science Reviews, 55, 91-102.

Ficker, E., Sonntag, G., Weber, E., 1980. Ansätze fur mechanischen Deutung des Rissentstehung bei Parabelrissen und Sichelbrüchen auf glazial geformten Felsoberflächen. Zeitschrift für Gletscherkunde und Glazialgeologie 16, 25-43. 
Geng, X., Zhang, Z., Barthel, E., Dalmas, D., 2010. Mechanical behavior of stiff coating on glass under sliding contact. Wear 269, 351-361.

Gilbert, G., 1906. Crescentic gouges on glaciated surfaces. Geological Society of America Bulletin 17, 303-316.

Glasser, N.F., Bennett, M.R., 2004. Glacial erosional landforms; origins and significance for palaeoglaciology. Progress in Physical Geography 28 43-75.

Hallet, B., 1979. A theoretical model of glacial abrasion. Journal of Glaciology 23, 39-50.

Hallet, B., 1981. Glacial abrasion and sliding: their dependence on the debris concentration in basal ice. Annals of Glaciology 2, 23-28.

Hallet, B., 1996. Glacial quarrying: a simple theoretical model. Annals of Glaciology 22, 1-8.

Hangl, M., Danzer, R., Paar, R., 1997. Edge toughness of brittle materials. In: Babini, G., Haviar, M., Sajgalik, P. (Eds.), Engineering Ceramics '96: Higher reliability through processing. NATO ASI Series 25, Springer, Netherlands, 327-335.

Harris, S., 1943. Friction cracks and the direction of glacial movement. Journal of Geology 51, 244-258.

Hildes, D.H.D., Clarke, G.K.C., Flowers, G.E., Marshall, S.J., 2004. Subglacial erosion and englacial sediment transport modelled for North American ice sheets. Quaternary Science Reviews 23, 409-430.

Hooyer, T., Cohen, D., Iverson, N., 2012. Control of glacial quarrying by bedrock joints. Geomorphology 153, 91101.

Iverson, N.R., 1991. Potential effects of subglacial water-pressure fluctuations on quarrying. Journal of Glaciology 37, 27-36.

Iverson, N.R., 2012. A theory of glacial quarrying for landscape evolution models. Geology 40, 679-682.

Kor, P.S.G., Shaw, J., Sharpe, D.R., 1991. Erosion of bedrock by subglacial meltwater, Georgian Bay, Ontario: a regional view. Canadian Journal of Earth Sciences 28, 623-642.

Krabbendam, M., Bradwell, T., 2011. Lateral plucking as a mechanism for elongate erosional glacial bedforms: explaining megagrooves in Britain and Canada. Earth Surface Processes and Landforms 36, 1335-1349.

Krabbendam, M., Bradwell, T., 2014 Quaternary evolution of glaciated gneiss terrains: pre-glacial weathering vs. glacial erosion. Quaternary Science Reviews 95, 20-42.

Krabbendam, M., Glasser, N., 2011. Glacial erosion and bedrock properties in NW Scotland: Abrasion and plucking, hardness and joint spacing. Geomorphology 130, 374-383.

Krabbendam, M., Eyles, N., Putkinen, N., Bradwell, T., Arbeleaz-Moreno, L., 2016. Streamlined hard beds formed by palaeo-ice streams: A review. Sedimentary Geology 338, 24-50.

Lahee, F., 1912. Crescentic fractures of glacial origin. American Journal of Science 33, 41-44.

Lawn, B., 1998. Indentation of ceramics with spheres: a century after Hertz. Journal of the American Ceramic Society 81, 1977-1994.

Lawson, T.J., 1996. Glacial striae and former ice movement; the evidence from Assynt, Sutherland. Scottish Journal of Geology 32 59-65.

MacDonald, A.M., Black, A.R., Dochartaigh, B.Ó., Everest, J., Darling, W.G., Flett, V., Peach, D.W., 2016. Using stable isotopes and continuous meltwater river monitoring to investigate the hydrology of a rapidly retreating Icelandic outlet glacier. Annals of Glaciology doi: 10.1017/aog.2016.22, 1-8.

MacGregor, K.R., Anderson, R.S., Waddington, E.D., 2009. Numerical modelling of glacial erosion and headwall processes in alpine valleys. Geomorphology 103, 189-204.

Melanson, A., Bell, T., Tarasov, L., 2013. Numerical modelling of subglacial erosion and sediment transport and its application to the North American ice sheets over the Last Glacial cycle. Quaternary Science Reviews 68, 154-174.

Morland, L.W., Boulton, G.S., 1975. Stress in an elastic hump: the effects of glacier flow over elastic bedrock. Proceedings of the Royal Society of London A344 A, 157-173.

Okko, V., 1950. Friction cracks in Finland. Bulletin de Commission Geologique Finlande 23, 45-50.

Petrovic, J.J., 2003. Review mechanical properties of ice and snow. Journal of Materials Science 38, 1-6.

Prest, V., 1983. Canada's Heritage of Glacial Features. Geological Survey of Canada, Miscellaneous Report 28, 119.

Prestvik, T., 1979. Geology of the Öræfi district, southeastern Iceland. Nordic Volcanological Institute Report 7901.

Quinn, J., Mohan, R., 2009. Geometry of edge chips formed at different angles. In: Lara-Curzio, E. (Ed.), Mechanical Properties and Performance of Engineering Ceramics and Composites. Wiley, 85-92.

Rastas, J., Seppälä, M., 1981. Rock jointing and abrasion forms on roches moutonnées, SW Finland. Annals of Glaciology 2, 159-163. 
Rea, B.R., 1994. Joint control in the formation of rock steps in the subglacial environment. In: Robinson, D.A., Williams, R.B.G. (Eds.), Rock weathering and landform evolution. , John Wiley, 473-486.

Rea, B.R., Evans, D.J.A., 1996. Landscapes of aerial scouring in NW Scotland. Scottish Geographical Magazine $112,47-50$.

Roberts, S., 2000. Hertzian testing of ceramics. British Ceramic Transactions 99, 31-38.

Schultz, R.A., 1995. Limits on strength and deformation properties of jointed basaltic rock masses. Rock Mechanics and Rock Engineering 28, 1-15.

Slocum, R.D., 1978. Friction cracks as directional indicators of glacial flow on Mt. Desert Island, Maine. Ohio Journal of Science 78, 11-17.

Smith, J.M., 1984. Experiments relating to the fracture of bedrock at the ice-rock interface. Journal of Glaciology 30, 123-125.

Stevenson, J., McGarvie, D., Smellie, J., Gilbert, J., 2006. Subglacial and ice-contact volcanism at the Öræfajökull stratovolcano, Iceland. Bulletin of Volcanology 68, 737-752.

Stoker, M.S., Bradwell, T., Howe, J.A., Wilkinson, I.P., McIntyre, K., 2009. Lateglacial ice-cap dynamics in NW Scotland: evidence from the fjords of the Summer Isles region. Quaternary Science Reviews 28, 31613184.

Thorarinsson, S., 1943. Vatnajökull, Scientific results of the Swedish-Icelandic Investigations 1936-37-38. Part XI: Oscillations of the Icelandic glaciers in the last 250 years. Geografiska Annaler 25, 1-25.

Thorarinsson, S., 1958. The Öraefajökull eruption of 1362. Acta Naturalia Islandica 2, 1-99.

Wintges, T., 1985. Studies on crescentic fractures and crescentic gouges with the help of close-range photogrammetry. Journal of Glaciology 31, 340-349.

Zaayman, E., Morrison, G., Field, J., 2009. Edge flaking in diamond. International Journal of Refractory Metals and Hard Materials 27, 409-416.

Zoet, L., Carpenter, B., Scuderi, M., Alley, R., Anandakrishnan, S., Marone, C., Jackson, M., 2013. The effects of entrained debris on the basal sliding stability of a glacier. Journal of Geophysical Research: Earth Surface $118,656-666$. 